\title{
Carbonate chemistry in sediment porewaters of the Rhône River delta driven by early diagenesis (northwestern Mediterranean)
}

\author{
Jens Rassmann ${ }^{1}$, Bruno Lansard ${ }^{1}$, Lara Pozzato ${ }^{1,2}$, and Christophe Rabouille ${ }^{1}$ \\ ${ }^{1}$ Laboratoire des Sciences du Climat et de l'Environnement, LSCE/IPSL, CEA-CNRS-UVSQ-Université \\ Paris Saclay, 91198 Gif-sur-Yvette, France \\ ${ }^{2}$ Institut Méditerranéen d'Océanologie, CNRS-IRD-Université de Toulon-Aix Marseille, 13288 Marseille, France \\ Correspondence to: Jens Rassmann (jens.rassmann@1sce.ipsl.fr)
}

Received: 17 May 2016 - Published in Biogeosciences Discuss.: 23 May 2016

Revised: 14 September 2016 - Accepted: 14 September 2016 - Published: 27 September 2016

\begin{abstract}
The Rhône River is the largest source of terrestrial organic and inorganic carbon for the Mediterranean Sea. A large fraction of this terrestrial carbon is either buried or mineralized in the sediments close to the river mouth. This mineralization follows aerobic and anaerobic pathways, with a range of impacts on calcium carbonate precipitation and dissolution in the sediment near the sediment-water interface. This study focuses on the production of dissolved inorganic carbon (DIC) and total alkalinity (TA) by early diagenesis, consequential $\mathrm{pH}$ variations and the effect on calcium carbonate precipitation or dissolution. The sediment porewater chemistry was investigated along a transect from the Rhône River outlet to the continental shelf. TA and concentrations of DIC, $\mathrm{SO}_{4}^{2-}$ and $\mathrm{Ca}^{2+}$ were analyzed on bottom waters and extracted sediment porewaters, whereas $\mathrm{pH}$ and oxygen concentrations were measured in situ using microelectrodes. The average oxygen penetration depth into the sediment was $1.7 \pm 0.4 \mathrm{~mm}$ close to the river mouth and $8.2 \pm 2.6 \mathrm{~mm}$ in the continental shelf sediments, indicating intense respiration rates. Diffusive oxygen fluxes through the sediment-water interface ranged between 3 and $13 \mathrm{mmol} \mathrm{O}_{2} \mathrm{~m}^{-2} \mathrm{~d}^{-1}$. In the first $30 \mathrm{~cm}$ of the sediment, TA and DIC porewater concentrations increased with depth up to $48 \mathrm{mmol} \mathrm{L}^{-1}$ near the river outlet and up to $7 \mathrm{mmol} \mathrm{L}^{-1}$ on the shelf as a result of aerobic and anaerobic mineralization processes. Due to aerobic processes, at all stations $\mathrm{pH}$ decreased by $0.6 \mathrm{pH}$ units in the oxic layer of the sediment accompanied by a decrease of the saturation state regarding calcium carbonate. In the anoxic layer of the sediments, sulfate reduction was the dominant mineralization process and was associated with an increase of porewater saturation state regarding calcium carbonate.
\end{abstract}

Ultimately anoxic mineralization of organic matter caused calcium carbonate precipitation demonstrated by a large decrease in $\mathrm{Ca}^{2+}$ concentration with depth in the sediment. Carbonate precipitation decreased in the offshore direction, together with the carbon turnover and sulfate consumption in the sediments. The large production of porewater alkalinity characterizes these sediments as an alkalinity source to the water column, which may increase the $\mathrm{CO}_{2}$ buffering capacity of these coastal waters. Estuarine sediments should therefore receive more attention in future estimations of global carbon fluxes.

\section{Introduction}

The coastal ocean is a net sink of atmospheric $\mathrm{CO}_{2}$ and plays an important role in the global carbon cycle (Hedges and Keil, 1995; Chen and Borgès, 2009; Bauer et al., 2013; Laruelle et al., 2013). This dynamic region is not only a sink for atmospheric $\mathrm{CO}_{2}$, but also a location where terrestrial organic and inorganic carbon is buried or recycled (Hedges and Keil, 1995; Cai, 2011). Due to strong pelagic-benthic coupling, a large fraction of organic matter (OM) is mineralized in continental shelf sediments (McKee et al., 2004; Burdige, 2011; Bauer et al., 2013). Estuaries and deltas are a very dynamic part of coastal ocean regions, characterized by high carbon turnover (Hedges and Keil, 1995; Cai, 2011). They are the principal link between continents and oceans, and receive inputs of terrestrial organic and inorganic carbon, in both particulate and dissolved phases (McKee et al., 2004; Cai, 2011; Dai et al., 2012; Bauer et al., 2013). An important 
fraction of these inputs remains on-site and undergoes oxic and anoxic mineralization (Andersson et al., 2005; Aller and Blair, 2006; Chen et al., 2012). Despite their importance for the coastal carbon cycle, there is a lack of knowledge about the links between early diagenesis and the carbonate system in river-dominated sediments (McKee et al., 2004).

Aerobic and anaerobic reaction pathways contribute to the production of dissolved inorganic carbon (DIC), resulting in the acidification of the bottom waters. Anaerobic reactions also lead to production of total alkalinity (TA) that increases the $\mathrm{CO}_{2}$ buffer capacity of seawater (Thomas et al., 2009). Variations in DIC and TA affect the partial pressure of $\mathrm{CO}_{2}$ $\left(p \mathrm{CO}_{2}\right)$ in seawater and ultimately the $\mathrm{CO}_{2}$ exchange with the atmosphere (Emerson and Hedges, 2008). By increasing the $\mathrm{CO}_{2}$ buffer capacity of seawater, the release of TA from anaerobic sediments into the water column could account for a majority of the $\mathrm{CO}_{2}$ uptake in shelf regions and deliver as much TA to the oceans as is derived from rivers (Thomas et al., 2009). Due to high dynamics, spatial heterogeneity and complex biogeochemical mechanisms, estimations of TA fluxes from the sediments are affected by high uncertainties (Krummins et al., 2013). The processes by which TA is produced in the sediments are still not well understood. Anaerobic respiration (e.g., denitrification, sulfate reduction, iron and manganese reduction) may play a major role, although dissolution/precipitation of calcium carbonate may also have a large impact on TA concentrations (Jahnke et al., 1997; Thomas et al., 2009; Krumins et al., 2013). Indeed, the changes in sediment porewater composition and $\mathrm{pH}$ can lead to over- or undersaturation of the calcium carbonate saturation state $(\Omega)$, and therefore influence carbonate dissolution and burial in sediments. Furthermore, carbonate dissolution was correlated to alkalinity fluxes across the sediment-water interface (SWI; Mucci et al., 2000).

Using in situ microelectrode measurements, Komada et al. (1998) and Cai et al. (2000) investigated small-scale changes in $p \mathrm{CO}_{2}, \mathrm{pH}$ and DIC in deep marine sediments and the associated exchange fluxes. In continental shelf sediments, Mucci et al. (2000) found that oxic mineralization can induce carbonate dissolution below the sediment-water interface, extending the observations of Jahnke et al. (1997) and Jahnke and Jahnke (2004) to coastal sediments. Burdige et al. $(2008,2010)$ pointed out that carbonate dissolution is also driven by oxic respiration in the shallow carbonated sediments of the Bahamas Banks. Concerning anoxic processes, Van Capellen and Wang (1996) demonstrated that high manganese and iron contents in the sediments of the Skagerrak (eastern North Sea) and associated OM mineralization can increase porewater $\mathrm{pH}$ by proton-consuming reduction processes of oxidized iron and manganese. These authors, with Froelich et al. (1979) and Berner (1980) as precursors, highlighted the complexity of the multiple competing reaction pathways in anoxic sediment.

In regions with a high carbon turnover, sulfate reduction is a large contributor to anoxic early diagenesis and can even be the dominant mineralization process for OM (Mucci et al., 2000; Burdige and Komada, 2011; Pastor et al., 2011a). Sulfate reduction slightly decreases $\mathrm{pH}$ (Jourabchi et al, 2005; Soetaert et al., 2007), but nevertheless, it tends to enhance carbonate precipitation because of its coupling with precipitation of sulfide minerals from iron oxides (Gaillard et al., 1989; Mucci et al., 2000; Burdige, 2011). As an example, in sapropelic sediments from Mangrove Lake, Mackenzie et al. (1995) reported a stable $\mathrm{pH}$ throughout the sulfatereduction zone and a buildup of supersaturation with respect to carbonate with depth. These results contrast with the theoretical perspective that sulfate reduction was supposed to lead to carbonate dissolution because of the $\mathrm{pH}$ decrease (Jourabchi et al., 2005). Even today, the reproduction of measured porewater profiles in the sediments and the estimation of TA and DIC fluxes across the SWI by modeling are very challenging (Arndt et al., 2013; Krumins et al., 2013; Jourabchi et al., 2005). In addition, the magnitudes of DIC and TA fluxes across the SWI are not well constrained and can vary significantly between different study sites (Mucci et al., 2000).

The objective of this study is to improve our understanding of the influence of early diagenesis of organic matter on carbonate dissolution and precipitation, and the production of DIC and TA. Therefore, we collected seawater and sediment samples along a transect from the Rhône River delta to the Mediterranean Sea continental shelf, covering a broad range of biogeochemical characteristics (Lansard et al., 2008; Cathalot et al., 2010; Cathalot et al., 2013). The Rhône River delta receives inputs of terrestrial organic and inorganic carbon, in both particulate and dissolved phases which decrease with the distance to the river mouth. The majority of these inputs remains on-site and undergoes mineralization in the sediments (Pastor et al., 2011a). Therefore sediments display strong spatial gradients in biogeochemical parameters such as nutrients, organic and inorganic carbon, affecting the diagenetic transport-reaction network (Bourgeois et al., 2011; Lansard et al., 2009). High sedimentation rates and resuspension events make this environment very dynamic and heterogeneous (Cathalot et al., 2010). The predominance of sediment accumulation over other dynamic processes and the absence of tidal mixing and dominant marine currents differentiate the prodelta of the Rhône from other deltaic environments like the Amazon, where the surface sediments are constantly reworked (Aller, 1998). Previous studies in this region often focused on organic matter mineralization pathways measurements in the oxic sediment layers and analysis of particulate carbon (Lansard et al., 2008; Cathalot et al., 2010) or could not provide simultaneous DIC and TA porewater measurements (Pastor et al., 2011a). These studies did not provide information on TA production and fluxes at the SWI. Accordingly, we designed a study to investigate the interaction of mineralization processes on porewater $\mathrm{pH}$ and the fate of solid calcium carbonates. For that purpose, we used a combination of in situ 
oxygen and $\mathrm{pH}$ microelectrode measurements and porewater analysis of DIC, TA, $\mathrm{SO}_{4}^{2-}$ and $\mathrm{Ca}^{2+}$ concentrations to examine various diagenetic pathways on different vertical scales. We investigated a transect of stations characterized by various biogeochemical conditions (from oxic-dominated to sulfate-reduction-dominated sediments). Furthermore, we calculated and discussed the calcium carbonate saturation state in regards to the different intensity of biogeochemical processes in these river-dominated sediments, and estimated how early diagenesis impacts the bottom water carbonate chemistry (DIC, TA and $p \mathrm{CO}_{2}$ ).

\section{Study site and methods}

\subsection{The Rhône River delta}

With a drainage basin of $97800 \mathrm{~km}^{2}$ and a mean waterdischarge of $1700 \mathrm{~m}^{3} \mathrm{~s}^{-1}$, the Rhône River is the largest river of the Mediterranean Sea in terms of freshwater discharge, inputs of sediment and terrestrial organic and inorganic matter (Pont, 1997; Durrieu de Madron et al., 2000; Sempéré et al., 2000). The Rhône River mouth is a wavedominated delta located in the microtidal Mediterranean environment of the Gulf of Lions (Sempéré et al., 2000). Its river plume is mostly oriented southwestward, due to the Coriolis effect and the wind forcing (Estournel et al., 1997). The annual discharge of particulate inorganic carbon (PIC) is estimated to be $0.68 \pm 0.45 \times 10^{9} \mathrm{gC} \mathrm{yr}^{-1}$ (Sempéré et al., 2009). The total particulate organic carbon (POC) deposition in the Rhône delta system $\left(265 \mathrm{~km}^{2}\right)$ is approximately $100 \pm 31 \times 10^{9} \mathrm{gC} \mathrm{yr}^{-1}$, with the deltaic front accounting for nearly $60 \%$ of the total POC deposition (Lansard et al., 2009). In front of the river mouth, the deposited sediments are of a cohesive nature and composed of fine-grained sediments (e.g., >90\% silt and clay; Roussiez et al., 2005; Lansard et al., 2007). Previous studies demonstrated that the carbonate content in the surface sediments varies between 28 and $38 \%$ (Roussiez et al., 2006), and the content of organic carbon (OC) varies between 1 and $2 \%$ (Roussiez et al., 2005, 2006; Lansard et al., 2008, 2009). The PIC in the sediments is composed of autochthonous and allochthonous carbonates, with the most abundant calcifying organisms in this area being foraminifera (Mojtahid et al., 2010).

The seafloor bathymetry shows that the delta is divided into three zones, characterized by different water depth, sedimentation rate and strength of bathymetric slope. Got and Aloisi (1990) defined three major domains: the proximal domain, in a radius of $2 \mathrm{~km}$ from the river outlet with water depth ranging from 10 to $30 \mathrm{~m}$; the prodelta domain, between 2 and $5 \mathrm{~km}$ from the river mouth with depth ranging from 30 to $70 \mathrm{~m}$; and the distal domain, with depth between 70 and $80 \mathrm{~m}$, which passed $5 \mathrm{~km}$ from the river mouth. Annual sedimentation rates reach up to $30-48 \mathrm{~cm} \mathrm{yr}^{-1}$ close to the river mouth (Charmasson et al., 1998) and rapidly decrease below

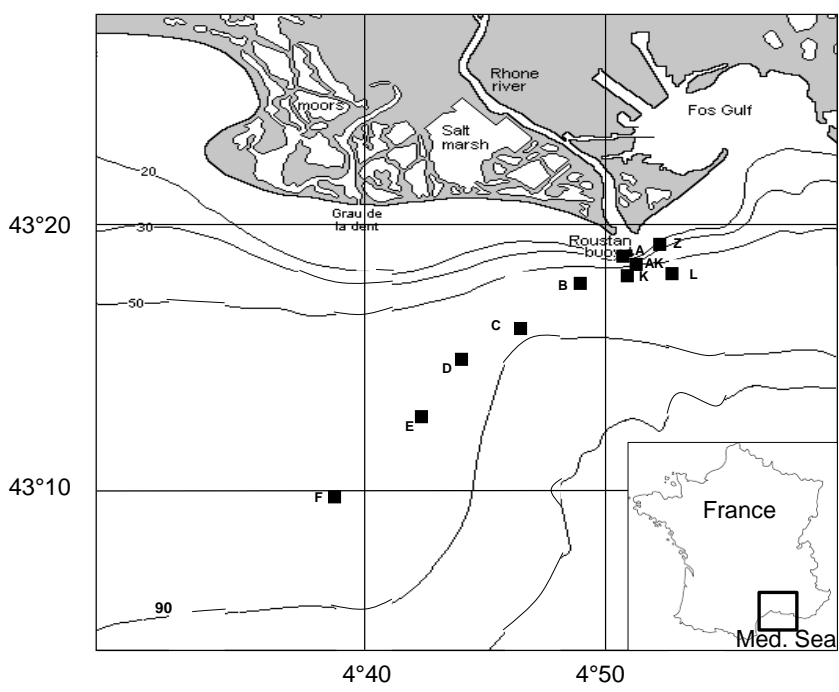

Figure 1. Map of the Rhône River mouth (northwestern Mediterranean Sea) with the stations investigated during the DICASE cruise in June 2014. The ocean bathymetry (in $\mathrm{m}$ ) is indicated by the continuous lines.

$0.1 \mathrm{~cm} \mathrm{yr}^{-1}$ on the continental shelf (Miralles et al., 2005). The seafloor in this region is a dynamic environment based on sediment deposition and accumulation and with important heterogeneity regarding diagenetic activities, sediment porewater profiles and exchange fluxes at the sediment-water interface (Lansard et al., 2009; Cathalot et al., 2010). Diffusive oxygen fluxes into the sediment show spatial variability, both with the distance from the river mouth (decreasing in offshore direction) and on the horizontal scale of a few squared centimeters (Lansard et al., 2009; Pastor et al., 2011b). Anoxic mineralization processes play a major role in the prodelta sediments and are dominated by iron and sulfur cycling (Pastor et al., 2011a).

\subsection{Sampling stations}

Ten stations were sampled along the main direction of the Rhône River plume during the DICASE oceanographic cruise that took place in the Gulf of Lions between 2-11 June 2014 on board the RV Tethys II (http://dx.doi.org/10. 17600/14007100). The positions and main characteristics of the sampling stations are shown in Fig. 1 and in Table 1. The stations were between 2 and $25 \mathrm{~km}$ distance from the Rhône River mouth, covering a bathymetric gradient ranging from 20 to $80 \mathrm{~m}$ of water depth and representing the three different domains (A, Z: proximal domain; AK, B, K, L: prodelta domain; and C, D, E, F: distal domain). The stations in the proximal domain $\mathrm{A}$ and $\mathrm{Z}$ have been sampled twice, in order to investigate spatial variability at these two stations. During this cruise, a benthic lander was used to measure in situ oxygen and $\mathrm{pH}$ micro profiles, and sediment cores were taken for porewater extraction and solid-phase analysis. 
Table 1. Stations investigated during the DICASE cruise in June 2014 with the main properties of bottom waters; dist denotes the distance from the Rhône River mouth.

\begin{tabular}{|c|c|c|c|c|c|c|c|c|c|c|c|c|}
\hline Station & $\begin{array}{l}\text { Long. } \\
\left({ }^{\circ} \mathrm{E}\right)\end{array}$ & $\begin{array}{l}\text { Lat. } \\
\left({ }^{\circ} \mathrm{N}\right)\end{array}$ & $\begin{array}{l}\text { Dist. } \\
(\mathrm{km})\end{array}$ & $\begin{array}{l}\text { Depth } \\
(\mathrm{m})\end{array}$ & $\begin{array}{c}T \\
\left({ }^{\circ} \mathrm{C}\right)\end{array}$ & Salinity & $\begin{array}{c}\mathrm{O}_{2} \\
\left(\mu \mathrm{mol} \mathrm{L}^{-1}\right)\end{array}$ & $\begin{array}{c}\text { DIC } \\
\left(\mu \mathrm{mol} \mathrm{L}^{-1}\right)\end{array}$ & $\begin{array}{c}\text { TA } \\
\left(\mu \mathrm{mol} \mathrm{L}^{-1}\right)\end{array}$ & $\mathrm{pH}_{\mathrm{t}}$ & $\begin{array}{c}\mathrm{SO}_{4}^{2-} \\
\left(\mathrm{mmol} \mathrm{L}^{-1}\right)\end{array}$ & $\begin{array}{c}p \mathrm{CO}_{2} \\
\text { (calculated) }(\mu \mathrm{atm})\end{array}$ \\
\hline $\mathrm{Z}, \mathrm{Z}^{\prime}$ & 4.865 & 43.317 & 2.2 & 18.0 & 16.0 & 37.5 & $244.0 \pm 0.3$ & $2330 \pm 1$ & $2648 \pm 3$ & $8.118 \pm 0.003$ & $28.4 \pm 0.3$ & 364.1 \\
\hline A, A' & 4.851 & 43.312 & 2.1 & 18.3 & 16.8 & 37.7 & $245.1 \pm 0.3$ & $2323 \pm 4$ & $2613 \pm 17$ & $8.072 \pm 0.004$ & $28.2 \pm 0.4$ & 407.3 \\
\hline $\mathrm{AK}$ & 4.856 & 43.307 & 2.8 & 48.1 & 15.8 & 37.4 & $240.8 \pm 0.1$ & $2335 \pm 4$ & $2623 \pm 3$ & $8.085 \pm 0.011$ & $29.7 \pm 0.3$ & 393.6 \\
\hline B & 4.818 & 43.295 & 3.0 & 66.2 & 15.0 & 37.7 & $213.2 \pm 0.8$ & $2372 \pm 5$ & $2628 \pm 2$ & $8.039 \pm 0.015$ & $28.7 \pm 0.3$ & 446.1 \\
\hline $\mathrm{K}$ & 4.856 & 43.302 & 3.3 & 60.5 & 14.9 & 37.7 & $226.4 \pm 0.2$ & $2351 \pm 5$ & $2538 \pm 5$ & $7.916 \pm 0.002$ & $29.1 \pm 0.3$ & 596.6 \\
\hline $\mathrm{L}$ & 4.885 & 43.304 & 4.4 & 58.2 & 15.2 & 37.6 & $230.9 \pm 0.6$ & $2340 \pm 2$ & $2612 \pm 5$ & $8.066 \pm 0.002$ & $29.7 \pm 0.3$ & 412.4 \\
\hline $\mathrm{C}$ & 4.773 & 43.271 & 8.8 & 75.0 & 14.4 & 37.7 & $225.6 \pm 0.4$ & $2354 \pm 2$ & $2621 \pm 10$ & $8.067 \pm 0.004$ & $29.0 \pm 0.3$ & 411.5 \\
\hline $\mathrm{D}$ & 4.738 & 43.256 & 12.8 & 80.0 & 14.9 & 37.6 & $214.5 \pm 0.5$ & $2388 \pm 8$ & $2605 \pm 3$ & $7.970 \pm 0.002$ & $30.2 \pm 0.3$ & 531.3 \\
\hline $\mathrm{E}$ & 4.685 & 43.219 & 17.9 & 77.3 & 14.3 & 37.7 & $226.3 \pm 0.3$ & $2391 \pm 6$ & $2594 \pm 5$ & $7.952 \pm 0.004$ & $30.4 \pm 0.3$ & 553.3 \\
\hline $\mathrm{F}$ & 4.649 & 43.164 & 24.3 & 77.0 & 14.8 & 37.7 & $230.2 \pm 0.1$ & $2364 \pm 4$ & $2600 \pm 24$ & $8.008 \pm 0.006$ & $30.3 \pm 0.3$ & 478.4 \\
\hline
\end{tabular}

The cruise took place during a period of low water discharge $\left(957 \mathrm{~m}^{3} \mathrm{~s}^{-1}\right)$ and air temperatures between 20 and $30^{\circ} \mathrm{C}$.

\subsection{In situ measurements}

To measure in situ oxygen and $\mathrm{pH}$ micro profiles at the sediment-water interface, an autonomous lander (Unisense ${ }^{\circledR}$ ) was used. This lander is equipped with a high precision motor capable of simultaneously moving five oxygen microelectrodes (Revsbech, 1989), two pH microelectrodes and a resistivity probe (Andrews and Bennet, 1981) with a vertical resolution of $100 \mu \mathrm{m}$. The recorded oxygen profiles were calibrated using oxygen concentrations measured in bottom waters by Winkler titration (Grasshoff et al., 1983) and the zero oxygen measured in the anoxic zone (Cai and Sayles, 1996). The SWI was positioned where the strongest vertical oxygen gradient was measured (Rabouille et al., 2003). The calibration of the $\mathrm{pH}$ electrodes was carried out using NBS buffers, thus allowing the estimation of the slope of the electrode signal as a function of $\mathrm{pH}$ variation at onboard temperature. The slope was then recalculated at in situ temperature, and the electrode signal variation was transformed into $\mathrm{pH}$ changes. The $\mathrm{pH}$ of bottom waters was determined using the spectrophotometric method with m-cresol purple following Clayton and Byrne (1993) and Dickson et al. (2007). Porewater $\mathrm{pH}$ on the total proton scale $\left(\mathrm{pH}_{\mathrm{t}}\right)$ was recalculated using the signal of the microelectrode adjusted to this $\mathrm{pH}$-bottom water value. At each depth, the profiler waited for $20 \mathrm{~s}$ to stabilize the electrode before measurements were recorded. Each data point is an average of five measurements carried out at every depth. For all in situ profiles, the signal drift of each microelectrode was examined to ensure it was $<5 \%$ from the beginning to the end of the measurements. The slope of the $\mathrm{pH}$ electrodes was double-checked to make sure it was at least $95 \%$ of the theoretical slope from the Nernst equation of $-59 \mathrm{mV}$ per $\mathrm{pH}$-unit at $25^{\circ} \mathrm{C}$. At each station, five oxygen profiles and two $\mathrm{pH}$ profiles were measured simultaneously on a sediment surface of $109 \mathrm{~cm}^{2}$.

\subsection{Calculation of oxygen fluxes across the sediment-water interface}

Sediment oxygen uptake rate has been widely used to assess benthic OC mineralization during early diagenesis. The total oxygen uptake (TOU) rate can be split into two parts: (i) the diffusive oxygen uptake rate (DOU) and (ii) the advective oxygen uptake. The DOU rates were calculated using Fick's first law (Berner, 1980):

$\mathrm{DOU}=-D_{s} \cdot \varphi{\frac{\mathrm{d}\left[\mathrm{O}_{2}\right]}{\mathrm{d} z}}_{z=0}$,

with:

- $D_{s}$ : apparent diffusion coefficient adjusted for diffusion in porous environment calculated following $D_{s}=$ $\frac{D_{o}}{1+3(1-\varphi)}$, where $D_{0}$ is the diffusion coefficient in free water according to Broecker and Peng (1974)

- $\phi$ : sediment porosity

- $\frac{\mathrm{d}\left[\mathrm{O}_{2}\right]}{\mathrm{d} z} z=0$ : oxygen gradient at the sediment-water interface.

\subsection{Sampling and ex situ measurements}

Bottom water samples were collected with a $12 \mathrm{~L}$ Niskin bottle as close as possible to the seafloor at each station. For these samples, temperature was measured using a digital thermometer with a precision of $0.1^{\circ} \mathrm{C}$, and salinity was measured using a salinometer with a precision of 0.1 . The $\mathrm{pH}$ and concentrations of DIC, TA and dissolved $\mathrm{O}_{2}$ were measured on board within $1 \mathrm{~h}$ for $\mathrm{pH}$ and within $6 \mathrm{~h}$ for DIC and TA. The pH of seawater was measured using a spectrophotometer and m-cresol purple as dye (Clayton and Byrne, 1993; Dickson et al., 2007), with uncertainties smaller than $0.01 \mathrm{pH}$ units. Oxygen concentrations were determined using Winkler titration with an average uncertainty of $0.4 \mu \mathrm{mol} \mathrm{L}^{-1}$. All DIC concentrations (bottom waters and porewaters) were measured on a DIC analyzer (Apollo SciTech ${ }^{\circledR}$ ) using $1 \mathrm{~mL}$ sample volume with 4 to 6 
replicates. The principle of the method is to acidify the sample with $10 \%$ phosphoric acid to transform all forms of DIC into $\mathrm{CO}_{2}$. The sample is then outgassed using ultra-pure nitrogen as a vector gas. The degassed $\mathrm{CO}_{2}$ is quantified by a LICOR $^{\circledR}$ gas analyzer, containing a non-dispersive infrared detector. To calibrate the method, a certified reference material (CRM batch no. 122, provided by A. Dickson, Scripps Institution of Oceanography) was used at least twice a day to confirm the accuracy of the DIC and TA measurements. TA concentrations were measured in a potentiometric open cell titration on $3 \mathrm{~mL}$ sample volume (Dickson et al., 2007). In our study, TA refers to total alkalinity, including silicates, phosphates, sulfides, organic alkalinity, etc. The DIC and TA uncertainties in the sediment porewaters were below $0.5 \%$.

Sediment cores were sampled using an UWITEC $^{\circledR}$ single corer $(60 \mathrm{~cm}$ length, $9.5 \mathrm{~cm}$ inner diameter). After sampling, the cores were rapidly introduced in a glove bag with a $\mathrm{N}_{2}$ atmosphere, to avoid oxidation, and porewaters were extracted using Rhizons, with pore size of $0.1-0.2 \mu \mathrm{m}$ (Seeberg-Elverfeldt et al., 2005). The Rhizons had been degassed and stored in a $\mathrm{N}_{2}$-filled gas tight box before use. Porewaters were extracted with a $2 \mathrm{~cm}$ vertical resolution and split into subsamples for DIC, TA, $\mathrm{SO}_{4}^{2-}$ and $\mathrm{Ca}^{2+}$ analysis. Sulfate concentrations were measured in the laboratory using a turbidimetric method (Tabatai, 1974). Concentrations of calcium ions were measured using ICP-AES (U1tima 2, Horiba ${ }^{\circledR}$ ) by the "Pôle Spectométrie Océan" in Brest (France) with a relative uncertainty of $0.75 \%$. The calcium concentrations were salinity-corrected by assuming constant $\mathrm{Na}^{+}$concentrations with depth in the porewater to avoid any evaporation effects due to sample storage. All bottom water concentrations were measured as triplicates. Small sample volumes in porewaters only allowed for replicates for the DIC, $\mathrm{SO}_{4}^{2-}$ and $\mathrm{Ca}^{2+}$ analysis but not for TA.

At each station, additional cores were taken for solidphase analysis. To establish porosity profiles, fresh sediment samples were weighed, dried for 1 week at $60^{\circ} \mathrm{C}$ and weighed again. Knowing the salinity and density of seawater and sediment, porosity was calculated from the weight loss after drying. Total carbonate content of the solid phase was analyzed using a manocalcimeter with uncertainties of $2.5 \%$ of $\mathrm{CaCO}_{3}$. A manocalcimeter is a small, gas-tight container where the sediment can be acidified with $\mathrm{HCl}$ to dissolve calcium carbonates. The resulting increase of pressure is measured with a manometer and is directly proportional to the carbonate content of the sediment sample. Sediment samples have also been analyzed to quantify the calcite/aragonite proportion via X-Ray diffraction (XRD) on a X-Pert Pro diffractometer, using the $\theta-\theta$ technique with the $\mathrm{K}-\alpha$-line of copper. The uncertainties of the XRD measurements were below $5 \%$ of the aragonite proportion (Nouet and Bassinot, 2007).

\subsection{Calculation of carbonate speciation, $\mathrm{CaCO}_{3}$ saturation states and $\mathrm{pH}$ in porewaters}

According to Orr et al. (2015), the best way to compute the nine parameters of the carbonate system at in situ conditions is to start with DIC and TA concentrations. The thermodynamic constants proposed by Lueker et al. (2000) were used to calculate DIC speciation and porewater $\mathrm{pH}$ with the program CO2SYS (Lewis and Wallace, 1998). The calcium carbonate saturation state, for both calcite and aragonite, is expressed as the solubility product of calcium and carbonate ions concentrations divided by their solubility constant $k_{\mathrm{sp}}$ :

$\Omega_{\mathrm{Ca}}=\frac{\left[\mathrm{Ca}^{2+}\right]\left[\mathrm{CO}_{3}^{2-}\right]}{k_{\mathrm{sp}}}$.

The solubility constant $k_{\mathrm{sp}}$ was calculated for in situ temperature, salinity and pressure following Millero (1979), Mucci (1983) and Millero (1995).

\section{Results}

\subsection{Bottom waters}

In June 2014, the Rhône River water discharge had been low and close to $1000 \mathrm{~m}^{3} \mathrm{~s}^{-1}$ for the previous 2 months. Accordingly, the extent and thickness of the Rhône River plume were limited and bottom waters were not influenced by the river outflow, even close to the river mouth. Bottom water temperature, salinity, $\mathrm{O}_{2}$, DIC, $\mathrm{TA}, \mathrm{pH}, \mathrm{SO}_{4}^{2-}$ and $p \mathrm{CO}_{2}$ are reported in Table 1 . Salinity remained very constant close to the seafloor, whereas temperature decreased with water depth from 16.8 to $14.3^{\circ} \mathrm{C}$. Bottom waters were well oxygenated and oxygen concentrations also decreased with increasing water depth. DIC and TA concentrations varied slightly, and the TA / DIC ratio in the bottom waters of all stations was $1.1 \pm 0.02$. The $\mathrm{pH}$ of bottom water was locally variable with a general decrease in offshore direction. $\mathrm{SO}_{4}^{2-}$ concentrations were constant between the stations with typical values for seawater around $30 \mathrm{mmol} \mathrm{L}^{-1}$. During the sampling period, the Integrated Carbon Observation System (ICOS) station at Manosque (l'Observatoire de Haute Provence, https://icos-atc.lsce.ipsl.fr/?q=OHP) measured a $p \mathrm{CO}_{2}$ of $410 \mathrm{ppm}$. At most stations, the bottom water $p \mathrm{CO}_{2}$ was oversaturated compared to the atmosphere, with the lowest values calculated close to the river mouth (stations $\mathrm{A}$ and $\mathrm{Z}$ ) and the highest values calculated at the shelf stations.

\subsection{The oxic layer}

Figure 2 shows all oxygen profiles measured in situ during the DICASE cruise. The oxygen penetration depth (OPD) into the sediment was $1.7 \pm 0.4 \mathrm{~mm}$ in the proximal domain, $3.3 \pm 1.3 \mathrm{~mm}$ in the prodelta domain and $8.2 \pm 2.6 \mathrm{~mm}$ 

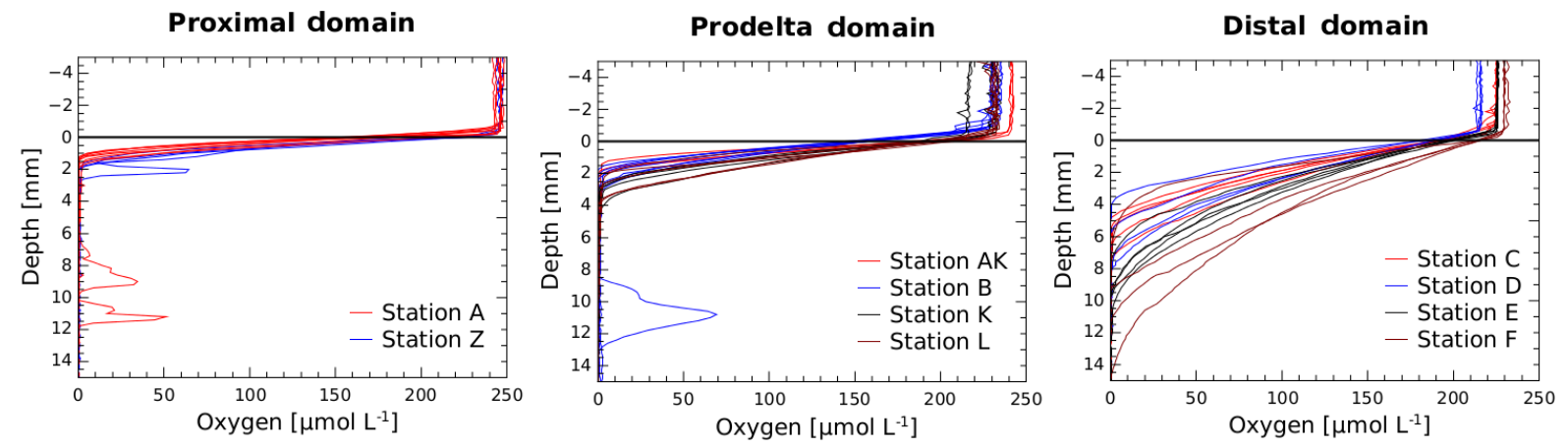

Figure 2. All in situ oxygen micro profiles measured during the DICASE cruise, in the proximal, prodelta and distal domains. The sedimentwater interface is marked by a horizontal line (depth $=0)$.

in the distal domain. Some profiles had burrows, creating small oxygen peaks below the OPD. The diffusive oxygen uptake rate (DOU) calculated from the measured oxygen profiles is plotted in Fig. 3 as a function of the distance to the river mouth in the direction of the river plume. The positive value signifies an uptake of $\mathrm{O}_{2}$ into the sediment. The DOU decreases exponentially with distance from $12.3 \pm 1.1 \mathrm{mmol} \mathrm{m}^{-2} \mathrm{~d}^{-1}$ at station A towards the minimum flux of $3.8 \pm 0.9 \mathrm{mmol} \mathrm{m}^{-2} \mathrm{~d}^{-1}$ at station $\mathrm{F}$.

In situ $\mathrm{pH}$ micro profiles were measured in the top $4 \mathrm{~cm}$ of the sediment at all stations (Fig. 4). Immediately below the SWI, the $\mathrm{pH}$ decreases by 0.6 to $0.7 \mathrm{pH}$ units in the oxic layer. Similarly to the oxygen micro profiles, the $\mathrm{pH}$ gradient in the OPD is stronger close to the river mouth and weaker in the distal domain. Just below the first drop, $\mathrm{pH}$ increases by $0.1-0.2 \mathrm{pH}$ units and tends towards an asymptotic value between 7.4 and 7.6. The $\mathrm{pH}$ inflexion point, i.e., where the $\mathrm{pH}$ decrease stops and $\mathrm{pH}$ starts increasing, is located deeper in the distal zone than in the proximal zone, just below the OPD. Note that $\mathrm{pH}$ profiles show high spatial heterogeneity, even at one station.

\subsection{DIC and TA porewater concentrations and calculated $\mathbf{p H}$}

Figure 5 shows the DIC and TA porewater profiles measured during the DICASE cruise. All porewater gradients across the sediment-water interface were strongest close to the river mouth and decreased in offshore direction. At the SWI, the DIC gradients were stronger than the TA gradients for all stations. Despite the spatial heterogeneity in the sediments, the three major areas defined by Got and Aloisi, 1990) in this region display different biogeochemical gradients. Accordingly, stations from each group will be reported and discussed separately. In the proximal domain (stations A and Z), DIC concentrations and TA increase immediately below the SWI and reach a maximum value of $48 \mathrm{mmol} \mathrm{L}^{-1}$ at $20 \mathrm{~cm}$ depth in the sediments, where the concentrations stabilize. In the prodelta domain (stations AK, B, K and L), DIC concentrations and TA increase to values of $5 \mathrm{mmol} \mathrm{L}^{-1}$ in the first

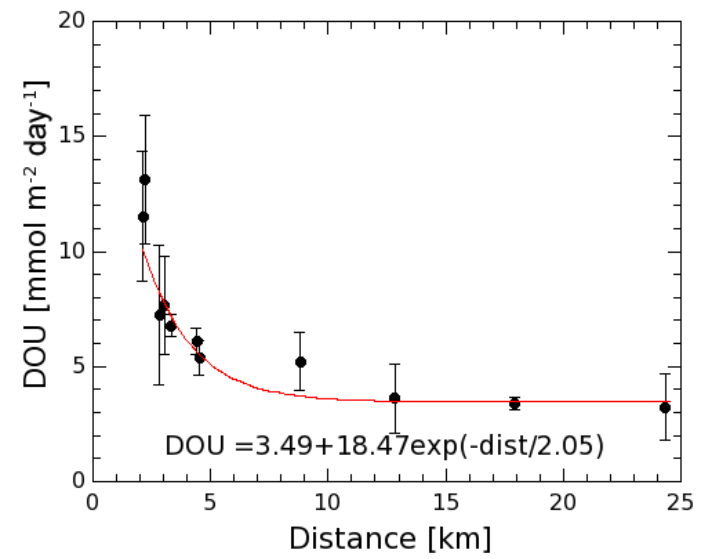

Figure 3. Diffusive oxygen uptake (DOU) across the sedimentwater interface as a function of the distance from the Rhône River mouth. The fluxes decrease exponentially following DOU $=F_{\min }+$ $A e^{(-x / t)}$, with $F_{\text {min }}$ being the flux in the offshore region, $x$ the distance to the river mouth in $\mathrm{km}$ and $A$ and $t$ being the numerical constants. Error bars are standard deviations between the diffusive fluxes calculated from the five single oxygen profiles measured at each station.

10 to $15 \mathrm{~cm}$ depth. Below this depth, the gradients become stronger and DIC concentrations increase with TA up to 12 to $15 \mathrm{mmol} \mathrm{L}^{-1}$ at the bottom of the cores (i.e., around $25 \mathrm{~cm}$ ). This succession of two different gradient shapes in the TA and DIC profile is also observed in the distal domain (stations $\mathrm{C}, \mathrm{D}, \mathrm{E}$ and $\mathrm{F}$ ), but the absolute values of the gradients are weaker. In the first 10 to $15 \mathrm{~cm}$, the concentrations reach values of $3.5 \mathrm{mmol} \mathrm{L}^{-1}$ and increase up to 5 to $7.5 \mathrm{mmol} \mathrm{L}^{-1}$ at the bottom of the core. These very high DIC concentrations in the sediment are related to large DIC and TA gradients, which are 4 to 10 times stronger in the proximal domain than at the other sites. The DIC and TA porewater profiles are well correlated in each core and the concentrations show a linear correlation with a slope of 1.01 and an $r^{2}$ of 0.998 (130 data points). 
Proximal domain

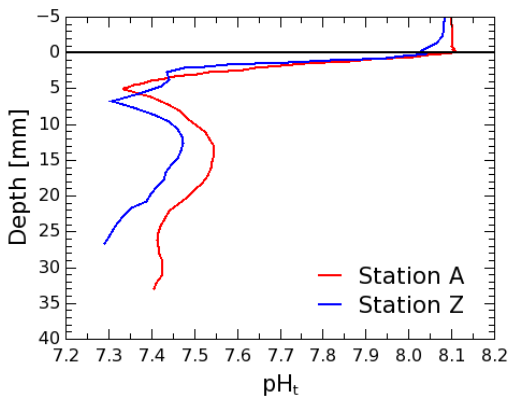

Prodelta domain

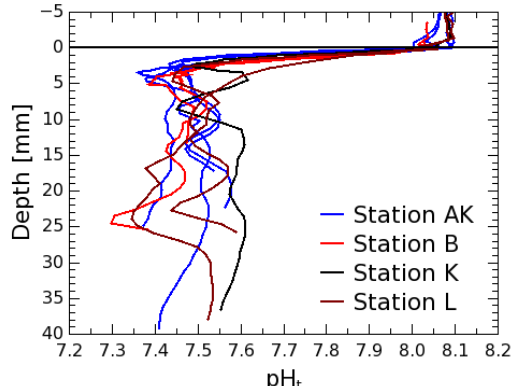

Distal domain

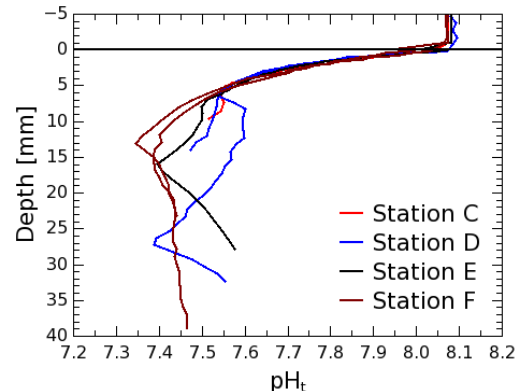

Figure 4. All $\mathrm{pH}_{\mathrm{t}}$ micro profiles measured during the DICASE cruise in the proximal, prodelta and distal domains. The sediment-water interface is marked by a horizontal line.
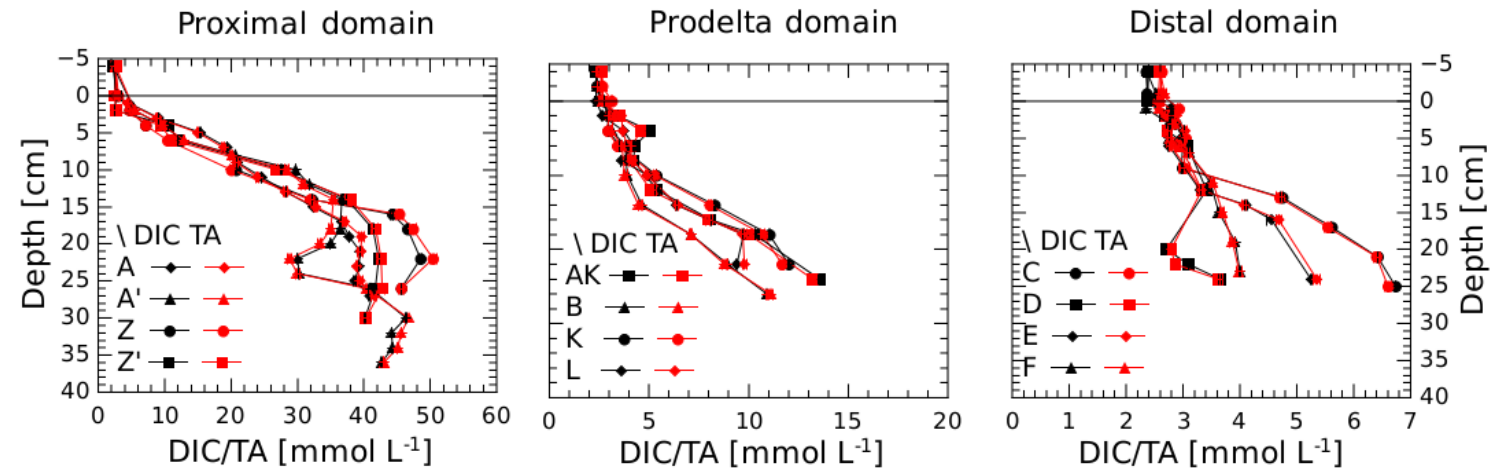

Figure 5. DIC (black) and TA (red) porewater profiles in the first $40 \mathrm{~cm}$ of sediment in the proximal, the prodelta and the distal domains. For a better visibility of the profiles in each domain, the scale of the concentrations has been individually adjusted for each domain.

The sediment $\mathrm{pH}$ profiles were calculated from TA and DIC concentrations using CO2SYS. The $\mathrm{pH}$ is reported on the total proton scale $\left(\mathrm{pH}_{\mathrm{t}}\right)$. In the first millimeter, the $\mathrm{pH}$ drops at all stations due to aerobic respiration (Fig. 6). Below the oxygen penetration depth, the $\mathrm{pH}$ varies between 7.2 and 7.8 and converges towards the range of 7.4 to 7.6.

Existing numerical tools have been developed for the oxic water column. Nevertheless, we used them in the sediments knowing that porewater concentrations (e.g., DIC, TA) are much larger than those in the water column and that reduced metabolites are unfortunately neglected. Despite this potential artifact, the calculated outputs (e.g., pH) agree with our measurements. A linear relationship of the $\mathrm{pH}$ data measured with microelectrodes against $\mathrm{pH}$ calculated by CO2SYS shows a correlation with a slope of $1.01 \pm 0.02$ and an $r^{2}$ of 0.7483 (graph not shown).

\subsection{Calcium and sulfate concentrations}

At all stations, bottom water $\mathrm{Ca}^{2+}$ concentration varies between 10 and $11 \mathrm{mmol} \mathrm{L}^{-1}$ (Fig. 7). In the proximal domain, the $\mathrm{Ca}^{2+}$ concentration decreases just below the SWI to reach a minimum of $2 \mathrm{mmol} \mathrm{L}^{-1}$ at $15-20 \mathrm{~cm}$ depth, where DIC and TA concentrations reach a maximum and sulfate concentration a minimum. In the prodelta domain, the $\mathrm{Ca}^{2+}$ concentration remains stable with depth until $10-15 \mathrm{~cm}$ in relation to the weaker TA and DIC gradients (Fig. 7). Below this depth, where the TA and DIC gradients increase, $\mathrm{Ca}^{2+}$ decreases to values around $7 \mathrm{mmol} \mathrm{L}^{-1}$ at the bottom of the cores. The distal domain is characterized by constant $\mathrm{Ca}^{2+}$ concentrations that remain above $10 \mathrm{mmol} \mathrm{L}^{-1}$, and the sulfate concentrations stay close to bottom water concentration.

In extracted sediment porewater, sulfate concentrations range from 5 to $32 \mathrm{mmol} \mathrm{L}^{-1}$ from the surface down to $30 \mathrm{~cm}$ depth. Our measurements indicate strong sulfate consumption rates in the proximal domain (Fig. 8) where DIC and TA gradients are strong as well. In the proximal domain, sulfate concentration decreases in the first centimeter below the SWI compared to the bottom water. In the prodelta domain, sulfate reduction starts to occur between 10 and $15 \mathrm{~cm}$ depth, the same depth where TA and DIC gradients increase. In the distal domain, no significant sulfate reduction occurs in the first $30 \mathrm{~cm}$, as sulfate concentration remains constant and TA and DIC gradients are low compared to the other domains.

\subsection{Solid carbonates and calcium carbonate saturation state}

The carbonate content of the solid phase was scattered around $35 \%$ at all stations, from the surface down to $30 \mathrm{~cm}$. 

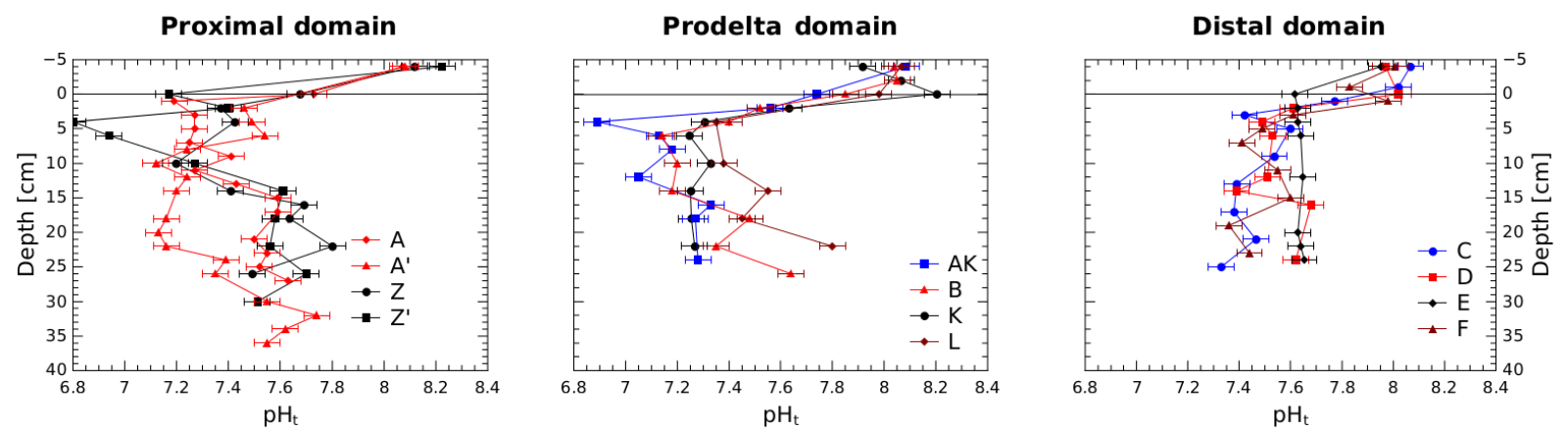

Figure 6. Calculated $\mathrm{pH}_{\mathrm{t}}$ porewater profiles of the proximal, the prodelta and the distal domains. The error bars are estimations of the error propagation from the measured data in the calculation.

Table 2. Diagenetic reactions and their effect on the carbonate system (TA, DIC, $\mathrm{pH}$ and $\Omega$ ).

\begin{tabular}{|c|c|c|c|c|c|}
\hline & & Reaction & $\Delta \mathrm{TA} / \Delta \mathrm{DIC}$ & $\Delta \mathrm{pH}$ & $\Delta \Omega$ \\
\hline & \multicolumn{5}{|l|}{ Carbonate chemistry } \\
\hline R1 & $\mathrm{CO}_{2}$ dissolution & $\mathrm{CO}_{2}+\mathrm{H}_{2} \mathrm{O} \leftarrow \rightarrow \mathrm{H}_{2} \mathrm{CO}_{3} \leftarrow \rightarrow \mathrm{HCO}_{3}^{-}+\mathrm{H}^{+} \leftarrow \rightarrow \mathrm{CO}_{3}^{2-}+2 \mathrm{H}^{+}$ & & - & - \\
\hline $\mathrm{R} 2 \mathrm{a}$ & Carbonate dissolution & $\mathrm{CaCO}_{3}+\mathrm{H}_{2} \mathrm{O}+\mathrm{CO}_{2} \rightarrow \mathrm{Ca}^{2+}+2 \mathrm{HCO}_{3}^{-}$ & $+2 / 1$ & + & + \\
\hline \multirow[t]{2}{*}{$\mathrm{R} 2 \mathrm{~b}$} & Carbonate precipitation & $\mathrm{Ca}^{2+}+2 \mathrm{HCO}_{3}^{-} \rightarrow \mathrm{CaCO}_{3}+\mathrm{H}_{2} \mathrm{O}+\mathrm{CO}_{2}$ & $-2 /-1$ & - & - \\
\hline & \multicolumn{5}{|l|}{ Aerobic reactions } \\
\hline R3 & Aerobic mineralization & $\mathrm{CH}_{2} \mathrm{O}+\mathrm{O}_{2} \rightarrow \mathrm{HCO}_{3}^{-}+\mathrm{H}^{+}$ & $0 / 1$ & - & - \\
\hline R4 & Nitrification & $\mathrm{NH}_{4}^{+}+2 \mathrm{O}_{2} \rightarrow \mathrm{NO}_{3}^{-}+\mathrm{H}_{2} \mathrm{O}+2 \mathrm{H}^{+}$ & $-2 / 0$ & - & - \\
\hline R5 & Iron oxidation & $4 \mathrm{Fe}^{\frac{4}{2+}}+\mathrm{O}_{2}+10 \mathrm{H}_{2} \mathrm{O} \rightarrow 4 \mathrm{Fe}(\mathrm{OH})_{3}+8 \mathrm{H}^{+}$ & $-8 / 0$ & - & - \\
\hline \multirow[t]{2}{*}{ R6 } & Manganese oxidation & $2 \mathrm{Mn}^{2+}+\mathrm{O}_{2}+4 \mathrm{HCO}_{3}^{-} \rightarrow 2 \mathrm{MnO}_{2}+4 \mathrm{CO}_{2}+2 \mathrm{H}_{2} \mathrm{O}$ & $-4 / 0$ & - & - \\
\hline & \multicolumn{5}{|l|}{ Anaerobic reactions } \\
\hline R7 & Nitrate reduction & $\mathrm{CH}_{2} \mathrm{O}+0.8 \mathrm{NO}_{3}^{-}+0.8 \mathrm{H}^{+} \rightarrow \mathrm{CO}_{2}+0.4 \mathrm{~N}_{2}+1.4 \mathrm{H}_{2} \mathrm{O}$ & $0.8 / 1$ & - & - \\
\hline $\mathrm{R} 8$ & Manganese reduction & $\mathrm{CH}_{2} \mathrm{O}+2 \mathrm{MnO}_{2}+3 \mathrm{H}^{+} \rightarrow \mathrm{HCO}_{3}^{-}+2 \mathrm{Mn}^{2+}+2 \mathrm{H}_{2} \mathrm{O}$ & $4 / 1$ & + & + \\
\hline R9 & Iron reduction & $\mathrm{CH}_{2} \mathrm{O}+4 \mathrm{Fe}(\mathrm{OH})_{3}+7 \mathrm{H}^{+} \rightarrow \mathrm{HCO}_{3}^{-}+4 \mathrm{Fe}^{2+}+10 \mathrm{H}_{2} \mathrm{O}$ & $8 / 1$ & + & + \\
\hline R10 & Sulfate reduction & $\mathrm{CH}_{2} \mathrm{O}+\frac{1}{2} \mathrm{SO}_{4}^{2-} \rightarrow \mathrm{HCO}_{3}^{-}+\frac{1}{2} \mathrm{HS}^{-}+\frac{1}{2} \mathrm{H}^{+}$ & $1 / 1$ & - & \\
\hline R11 & FeS precipitation & $\mathrm{Fe}^{2+}+\mathrm{HS}-\stackrel{4}{\rightarrow} \mathrm{FeS}+\mathrm{H}^{+}$ & $-2 / 0$ & - & - \\
\hline R12 & FeS precipitation with sulfate recycling & $8 \mathrm{Fe}(\mathrm{OH})_{3}+9 \mathrm{HS}^{-}+7 \mathrm{H}^{+} \rightarrow 8 \mathrm{FeS}+\mathrm{SO}_{4}^{2-}+20 \mathrm{H}_{2} \mathrm{O}$ & $-2 / 0$ & + & + \\
\hline R14 & Pyrite precipitation & $8 \mathrm{Fe}(\mathrm{OH})_{3}+15 \mathrm{HS}^{-}+\mathrm{SO}_{4}^{2-}+17 \mathrm{H}^{+} \rightarrow 8 \mathrm{FeS}_{2}+28 \mathrm{H}_{2} \mathrm{O}$ & $2 / 0$ & + & + \\
\hline R15 & Anaerobic methane oxidation & $\mathrm{CH}_{4}+\mathrm{SO}_{4}^{2-} \rightarrow \mathrm{HS}^{-}+\mathrm{HCO}_{3}^{-}+\mathrm{H}_{2} \mathrm{O}$ & $2 / 1$ & $+($ if $\mathrm{pH}<7.9$ ) & + \\
\hline R16 & Methanogenesis & $\mathrm{CH}_{2} \mathrm{O} \rightarrow \frac{1}{2} \mathrm{CH}_{4}+\frac{1}{2} \mathrm{CO}_{2}$ & $0 / 0.5$ & - & - \\
\hline
\end{tabular}

The composition of sedimentary $\mathrm{CaCO}_{3}$ was dominated by calcite $(\approx 95 \%)$, with a small fraction of magnesian calcite $(<5 \%)$, and only traces of aragonite (data not shown). Accordingly, only $\Omega_{\text {calcite }}$ is reported since calcite is dominant and aragonite is insignificant in the sedimentary $\mathrm{CaCO}_{3}$. The $\mathrm{CaCO}_{3}$ saturation state, calculated with CO2SYS from our TA / DIC and $\mathrm{Ca}^{2+}$ data, is presented in Fig. 9 for the three domains. At all stations, the calcite saturation state in porewaters drops in the oxic layer. In the proximal domain (Fig. 9), the saturation state increases immediately below this first drop to reach very high values of around 5 to 10 . In the prodelta domain, the saturation state remains very close to 1 at a depth between 5 and $10 \mathrm{~cm}$, before increasing to super saturation ( 3 to 4 ) below 10 to $15 \mathrm{~cm}$ depth. In the distal domain, the saturation state shows no variation below the first drop into the sediment.

\section{Discussion}

\subsection{Principal diagenetic reactions and their influence on the carbonate system}

As the diagenetic transport-reaction network is complex, so are the interactions of these reactions with carbonate chemistry (Krumins et al., 2013). Table 2 summarizes the main diagenetic reactions (simplified) and their impact on DIC and TA porewater concentrations. DIC is always produced by OM mineralization and decreases $\mathrm{pH}$, whereas the TA budget of these reactions and the resulting $\mathrm{pH}$ variation can be positive or negative (Soetaert et al., 2007). The dissolution and dissociation of metabolic (or atmospheric) $\mathrm{CO}_{2}$ in seawater results in the formation of carbonic acid (R1) and the consumption of $\mathrm{CO}_{3}^{2-}$, and ultimately leads to carbonate dissolution (R2a; Soetaert et al., 2007; Emerson and Hedges, 


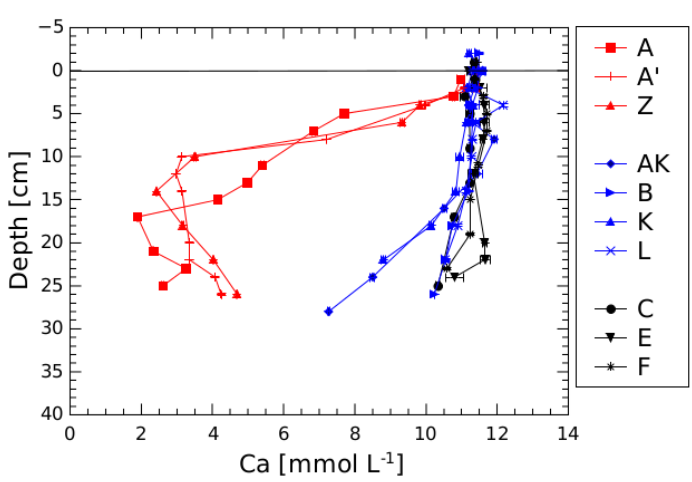

Figure 7. Porewater concentrations of $\mathrm{Ca}^{2+}\left(\mathrm{mmol} \mathrm{L}^{-1}\right)$; proximal domain in red, prodelta domain in blue and distal domain in black. The error bars represent the uncertainties of the ICP-AES measurements.

2008). Aerobic mineralization consumes $\mathrm{O}_{2}$ and produces $\mathrm{CO}_{2}$, decreasing $\mathrm{pH}$ without TA production (R3), and finally decreases $\Omega$. In the sediments, oxygen is also used to reoxidize reduced species, a process that decreases $\mathrm{pH}$ even more strongly than aerobic respiration (R4-6), and thus reoxidation decreases $\Omega$ as well (Jourabchi et al., 2005; Glud, 2008). In contrast, anaerobic mineralization causes much weaker $\mathrm{pH}$ reductions compared to the oxic processes and can even increase pH (R7-10; Jourabchi et al., 2005; Soetaert et al., 2007). OM mineralization by nitrate reduction produces DIC and TA, has been related to TA release from the sediments and is even estimated to be a major TA source to the oceans (Thomas et al., 2009). Sulfate reduction is usually associated with a weak decrease in $\mathrm{pH}$, although with significant DIC and TA production (Mucci et al., 2000; Jourabchi et al., 2005). The resulting sulfide ions can either diffuse towards the surface to be oxidized within the oxic layer or precipitate with iron. The precipitation of sulfur minerals does not affect the amount of porewater DIC, but can have a major influence on pH and TA (R11-13; Soetaert et al., 2007). The two reactions R14 and R15 deal with the coupling of sulfate reduction and methanogenesis and its impact on DIC.

In the Rhône River delta sediments, OM mineralization leads to DIC production, and under anoxic conditions, also to TA production. Our results demonstrate strong DIC and TA porewater gradients in the anoxic layer of the sediments, indicating high anaerobic respiration rates. As a result, DIC and TA diffuse towards the SWI. No reaction in the oxic zone consumes DIC except potential carbonate precipitation. Our results indicate that more DIC is produced in the sediments than consumed by precipitation of $\mathrm{CaCO}_{3}$. This means that $\mathrm{OM}$ mineralization in the sediments leads to strong DIC fluxes from the sediments into the water column. For TA, the situation is more complicated, as oxidation of reduced species can consume as much TA as has been produced to reduce these species (Table 2). In a 1-D system, where no precipitation occurs and no reduced species can be exported, an important fraction of the anaerobic TA would be consumed in the oxic layer. Denitrification forms an exception to this, as the reduced end product $\mathrm{N}_{2}$ of this reaction can escape the sediments. Thus the TA produced by denitrification is not consumed in the oxic sediment layer.

Krumins et al. (2013) reported that the effective TA flux from the sediments into the water column is far less important than the anaerobic TA production due to the TA loss in the oxic layer. Unfortunately, the resolution of the DIC and TA porewater profiles in this current study does not give precise information about the gradients in the oxic layer. Thus, we can only speculate about the oxic TA consumption in this region and related TA fluxes across the SWI. According to Pastor et al. (2011a), $97 \%$ of the reduced species precipitate in the anoxic sediments in the Rhône prodelta. Therefore, the majority of the produced TA is likely released into the water column, which can counterbalance the effects of the DIC fluxes and increase the $\mathrm{CO}_{2}$ buffer capacity of the overlaying waters.

\subsection{The impact of oxic and suboxic processes on the carbonate system}

The upper part of the sediment is defined as the oxic zone, supporting aerobic respiration (R3 - Table 2). Generally, the oxygen penetration depth (OPD) is related to respiration rates (Cai and Sayles, 1996). Aerobic respiration consumes $\mathrm{O}_{2}$ to mineralize organic matter, produces metabolic $\mathrm{CO}_{2}$ in the sediment porewater, increases the DIC concentration, lowers $\mathrm{pH}$ and possibly decreases the $\mathrm{CaCO}_{3}$ saturation state (Cai et al., 1993, 1995). The OPD and oxygen fluxes are therefore key parameters to assess the effect of aerobic respiration on calcium carbonate in the sediment (Jahnke et al., 1997; Jahnke and Jahnke, 2004).

In the Rhône River delta, the OPD increases with water depth and distance from the Rhône River mouth as reported in previous studies (Lansard et al., 2008, 2009; Cathalot et al., 2010). These low values of $\mathrm{O}_{2}$ penetration depths are typical of river-dominated ocean margins and they depend mainly on the sedimentation rate, the OM flux, the age and the oxidation state of OM (Lansard et al., 2009; Cathalot et al., 2013). Few in situ $\mathrm{O}_{2}$ profiles show oxygen peaks at depth below the OPD. These are likely the effect of sediment bioturbation by the benthic macrofauna. As reported by Bonifácio et al. (2014), the macrofauna community is dominated by polychaetes and the highest activity is found in the prodelta domain. Nevertheless, comparisons between TOU and DOU rates have demonstrated that the DOU accounts for about $80 \%$ of total oxygen uptake rate into the sediments (Lansard et al., 2008). As a consequence, diffusive transport is dominant compared to advective transport and bioturbation (i.e., bioirrigation and bioventilation). Diffusive $\mathrm{O}_{2}$ fluxes calculated from in situ 1-D micro profiles (Fig. 2) are therefore representative of total oxygen uptake rates. As shown in Fig. 3, the diffusive oxygen fluxes into 

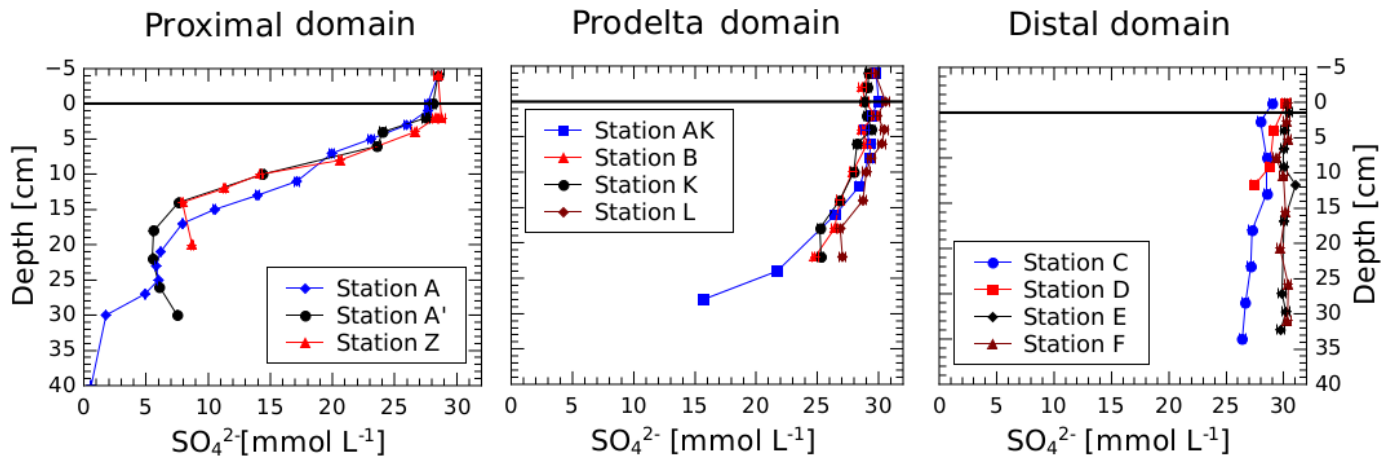

Figure 8. Sulfate profiles measured in the porewaters $\left(\mathrm{mmol} \mathrm{L}^{-1}\right)$ of the proximal, the prodelta and in the distal domains.
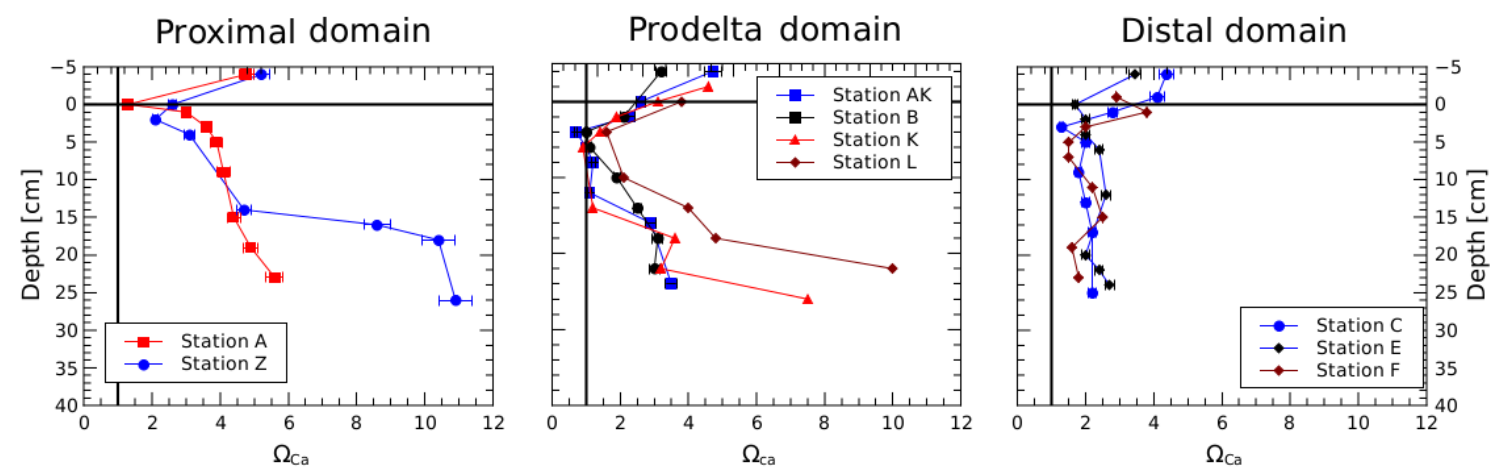

Figure 9. Porewater calcium carbonate saturation state $(\Omega)$ of the proximal, prodelta and distal domains. The saturation limit for calcium carbonates dissolution/precipitation $(\Omega=1)$ is marked by a vertical line.

the sediment decrease exponentially with the distance from the river mouth, from $12.3 \pm 1.1 \mathrm{mmol} \mathrm{O}_{2} \mathrm{~m}^{-2} \mathrm{~d}^{-1}$, close to the Rhône River mouth, to $3.8 \pm 0.9 \mathrm{mmol} \mathrm{O}_{2} \mathrm{~m}^{-2} \mathrm{~d}^{-1}$ offshore. According to Pastor et al. (2011a), the POC flux in the proximal domain is 1 order of magnitude higher than in the offshore regions of the Rhône prodelta. This OM flux, especially its labile fraction, supports oxygen consumption and is completely mineralized in the oxic layer (Pastor et al., 2011a).

During aerobic respiration, the ratio of oxygen to DIC during $\mathrm{OM}$ mineralization is close to 1 , according to the stoichiometry of reaction R3 (Table 2). As a result, DIC concentrations increase just below the SWI at all stations (Fig. 5). The balance between $\mathrm{O}_{2}$ flux and carbon oxidation in the sediment is affected by $\mathrm{O}_{2}$ consumption linked to the oxidation of inorganic species produced via anoxic OC degradation $\left(\mathrm{NH}_{4}^{+}, \mathrm{Fe}^{2+}, \mathrm{Mn}^{2+}\right.$ and $\left.\mathrm{HS}^{-}\right)$. The oxidation of reduced diagenetic products has a profound effect on porewater $\mathrm{O}_{2}$ and $\mathrm{pH}$ profiles in $\mathrm{O}_{2}$ limited sediments (Cai and Reimers, 1993). These reactions (R4 to R6), in addition to aerobic bacterial respiration, consume TA and decrease porewater $\mathrm{pH}$ and therefore decrease the calcium carbonate saturation state as well.

There is a large contribution of anoxic processes to total OM mineralization in sediments near the Rhône River mouth, certainly due to large inputs of fresh organic material combined with high sedimentation rates (Pastor et al., 2011a). The diagenetic byproducts originally produced during anoxic mineralization are almost entirely precipitated and buried in the sediment, which leads to a relatively low contribution of the re-oxidation of reduced products to total oxygen consumption. Still, between 10 and $40 \%$ of the oxygen flux is used to oxidize reduced species of iron and manganese, contributing to lower pH (Pastor et al., 2011a). Again, the upward flux of reduced species in the sediments is higher in the proximal domain than in the others. Offshore, less OM is available and the diagenetic activity is weaker, providing less reduced species from deeper sediment layers. The $\mathrm{pH}$ drops below the SWI, caused by all oxic processes, are visible on the in situ $\mathrm{pH}$ micro profiles and decrease until the OPD is reached (Figs. 2 and 4). As the OPD is smaller and the oxygen fluxes are higher in the proximal domain, the $\mathrm{pH}$ minima are reached at shallower depth in the sediment than in the other domains. The $\mathrm{pH}$ drop is lowering $\Omega$ by consuming carbonate ions (Emerson and Hedges, 2008; Jourabchi et al., 2005). The decrease of $\Omega$, due to both aerobic respiration and the oxidation of reduced species, is clearly visible between the first two points located above and below the SWI interface (Fig. 9). 


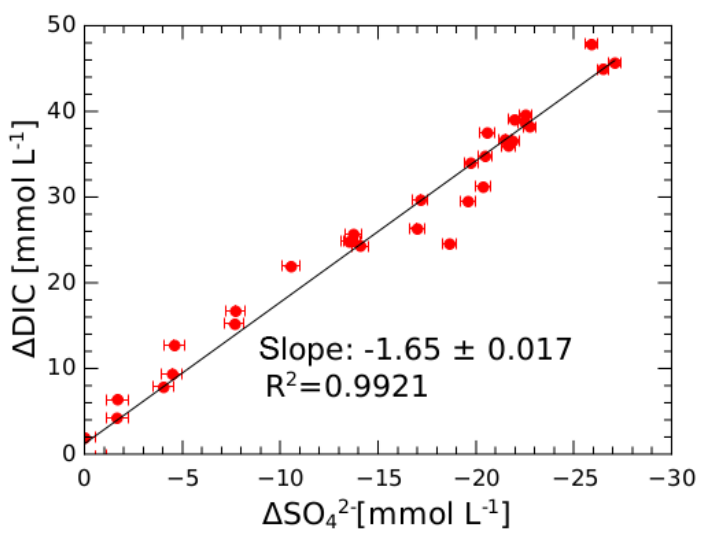

Figure 10. Scatter plot of $\Delta \mathrm{DIC}$ vs $\Delta \mathrm{SO}_{4}^{2-}$ with linear regression. $\Delta$ designates the difference between the corresponding porewater and bottom water concentration. The slope of the correlation is $-1.65 \pm 0.017$ with a correlation coefficient of $r^{2}=0.992$.

In agreement with the current understanding of anoxic diagenesis, the observed $\mathrm{pH}$ increase of 0.1 to 0.2 units below the OPD can be attributed to OM mineralization via reduction of iron and manganese (R8 and R9 - Table 2). These anoxic reactions release TA and increase $\mathrm{pH}$ in the oxicanoxic transition zone (Aguilera et al., 2005; Jourabchi et al., 2005). This $\mathrm{pH}$ increase and the release of TA create a strong increase in the porewater saturation state $(\Omega)$. Previous research indicated that the turnover of $\mathrm{Fe}$ and $\mathrm{Mn}$ is high in the sediments close to the river mouth (Pastor et al., 2011a). The first porewater data point sampled in the sediments represents a mixture of oxic and anoxic porewater. Therefore, we potentially overestimate $\Omega$ in the oxic layer based on calculations from porewater concentrations (Cai et al., 2010). Different measurements in the deep sea revealed that $\Omega$ shows a minimum in the oxic layer (Cai et al., 1993, 1995, 1996; Hales and Emerson, 1997). As pH decreased at all stations to the same value, but the TA and DIC gradients at the interface are the strongest in the proximal domain, $\Omega$ should show the highest values in the oxic sediments of the proximal domain and decrease in offshore direction. High TA concentrations in the oxic layer, resulting from anoxic OM mineralization below, prevent the carbonate saturation state from getting below 1. Thus, potential dissolution in the oxic layer would most likely occur in the distal domain, but could be inhibited in the proximal domain.

In contrast to other nearshore environments, nitrate reduction has been shown to only account for $2-5 \%$ of OM mineralization in the sediments of the prodelta of the Rhône, whereas other anaerobic mineralization processes account for $30-40 \%$ in the distal domain and up to $90 \%$ in the proximal domain (Pastor et al., 2011a). Nitrate reduction produces less TA than DIC (TA / DIC ratio $=0.8 / 1$ ), and thus lowers $\Omega$ in the porewaters. Nevertheless, denitrification is a net TA source from the sediments to the bottom water as the end product $\mathrm{N}_{2}$ undergoes no further oxidation.
Finding this clear succession of reactions is interesting, particularly the $\mathrm{pH}$ profiles that look typical in the aerobic sediment layers sampled from this complex and dynamic system. As OPDs only measure a couple of millimeters, molecular diffusion is by far the dominant transport process (Peclet number $\gg 1$ on a scale of the OPD). The microstructure of these sediments is restored very fast after disturbances like resuspension events (Toussaint et al., 2014). Furthermore, the comparison with previous studies shows that despite the high sediment dynamics in this region, the general biogeochemical tendencies are maintained throughout time.

\subsection{Sulfate reduction and its impact on carbonate chemistry}

With sulfate concentration in seawater around $30 \mathrm{mmol} \mathrm{L}^{-1}$, $\mathrm{SO}_{4}^{2-}$ reduction can generate large amounts of DIC and TA during organic matter mineralization through sulfate reduction. Indeed, in organic rich sediments, sulfate reduction can account for the majority of OM mineralization (Gaillard et al., 1989; Jourabchi et al., 2005; Burdige, 2011; Fenschel et al., 2012). Following reaction R9, two units of DIC and TA are produced for one unit of sulfate consumed (Mucci et al., 2000; Krumins et al., 2013).

To estimate the actual $\Delta \mathrm{DIC} / \Delta \mathrm{SO}_{4}^{2-}$ ratio due to diagenetic processes, the slope of the correlation between produced DIC $(\triangle \mathrm{DIC})$ and consumed sulfates $\left(\Delta \mathrm{SO}_{4}^{2-}\right)$ in the porewaters (Fig. 10) has to be corrected for molecular diffusion following the equation proposed by Berner (1980). Accordingly, we used the diffusion coefficients determined by Li and Gregory (1973). Below $10 \mathrm{~cm}$ depth, the observed diffusion-corrected $\Delta \mathrm{DIC} / \Delta \mathrm{SO}_{4}^{2-}$ ratio equals $1.8 \pm 0.02$. The deviation of this measured value, from the theoretical value of 2 , can be linked to higher oxidation states of organic matter, which increases the $\mathrm{SO}_{4}^{2-}$ requirement for DIC production (in an extreme case, if methane undergoes oxidation, the $\Delta \mathrm{DIC} / \Delta \mathrm{SO}_{4}^{2-}$ ratio equals 1), carbonate precipitation lowering DIC concentrations or methanogenesis that increases DIC without consuming $\mathrm{SO}_{4}^{2-}$ (Burdige and Komada, 2011; Antler et al., 2014). All three factors may interact in the proximal zone. A large OM fraction in this zone is of terrestrial origin, aged and partly oxidized before being deposited (Cathalot et al., 2013). Calcium carbonates precipitate in the porewaters of these sediments (Fig. 7) and lower DIC concentrations. In addition, the presence of methane has been reported by Garcia-Garcia et al. (2006).

As demonstrated by Burdige (2011) and Burdige and Komada (2011), the interactions of all diagenetic pathways are hard to disentangle and do not provide clear evidence of changes in the $\triangle \mathrm{DIC} / \Delta \mathrm{SO}_{4}^{2-}$ ratio. Nonetheless, the value of the observed $\Delta \mathrm{DIC} / \Delta \mathrm{SO}_{4}^{2-}$ ratio $(1.8 \pm 0.1)$ points towards the dominance of sulfate reduction in the deeper layers of the sediment (below $10 \mathrm{~cm}$ depth). Despite all these diverse reactions that affect the $\Delta \mathrm{DIC} / \Delta \mathrm{SO}_{4}^{2-}$ ratio, they are balanced in a way that $\triangle \mathrm{DIC}$ and $\Delta \mathrm{SO}_{4}^{2-}$ correlate well and 
do not show a deviation in the slope throughout the whole sediment depth investigated (Fig. 10).

Sulfate reduction is also attested by the co-production of alkalinity and DIC (Fig. 5), which is by far the most important alkalinity producer in marine sediments (Krumins et al., 2013). Sulfate reduction creates a TA / DIC ratio very close to 1 in the porewaters. This situation is very similar to Mangrove Lake sediments (Mackenzie et al., 1995) where depletion of sulfate is almost complete and DIC and TA concentrations build up to $40 \mathrm{mmol} \mathrm{L}^{-1}$ in the sediment porewaters, or to other coastal environments (Burdige, 2011; Antler et al., 2014). No other reaction in the anoxic zone has a TA / DIC production ratio near 1 . As $\mathrm{pH}$ is buffered, probably by precipitation of $\mathrm{FeS}$ and $\mathrm{FeS}_{2}$ (R12), this large increase of alkalinity is accompanied, in the proximal zone, by a large increase of the saturation state of porewaters with respect to calcite (Fig. 9) up to values of oversaturation $(\Omega)$ from 5 to 10.

The effect of sulfate reduction and the carbonate saturation state has been a matter of debate since the early work of Ben-Yaakov (1973). Indeed, sulfate reduction produces large quantities of both alkalinity, which increases $\Omega$, and protons, which decrease $\Omega$. This has been summarized in a model by Jourabchi et al. (2005) by estimating that sulfate reduction would lead to a decrease of $\Omega$ if it were the only ongoing reaction. The sediments from the proximal area of the Rhône River delta show, on the contrary, that $\mathrm{pH}$ stabilizes between 7.2 and 7.6. In these sediments, mineralization is driven by sulfate reduction that generates an increase of saturation state with respect to calcite (Fig. 9). This situation is very similar to Mackenzie et al. (1995) and Mucci et al. (2000), who also showed an increase of $\Omega$ when sulfate reduction is significant. Using a closed system model, Ben Yaakov (1973) estimated that oxidation of $\mathrm{HS}^{-}$coupled to iron hydroxide reduction with $\mathrm{FeS}$ precipitation (as in R11 or R12) would buffer or even increase $\mathrm{pH}$.

The Rhône River is known to be the most important riverine input of iron into the Mediterranean Sea (Guieu et al., 1991) with an iron content varying between 2 and $4 \%$ in the solid-phase discharge. In the proximal zone of the Rhone Delta, dissolved sulfide is absent from the first tens of centimeters in the sediment (Pastor et al., 2011a), indicating that re-oxidation and/or precipitation of sulfide is occurring in these sediments. Pastor et al. (2011a) estimated that sulfides are the limiting factor for pyrite precipitation in this environment. Therefore, Charles et al. (2014) suggested that OM mineralization in the prodelta of the Rhône could be coupled to pyritization. With this important FeS coupling, $\mathrm{pH}$ is stabilized or tends to increase, and a large oversaturation with respect to calcium carbonate is created due to produced carbonate ions.

In the proximal domain, the large super saturation, with respect to calcite, induces calcite precipitation as evidenced by a large decrease of dissolved calcium in the porewaters (Gaillard et al., 1989; Boudreau et al., 1992). Indeed, $\mathrm{Ca}^{2+}$ concentration decreases by $9 \mathrm{mmol} \mathrm{L}^{-1}$ between the bottom water and $25 \mathrm{~cm}$ depth in proximal sediments. This precipitation consumes about 10 to $15 \%$ of anaerobically produced DIC and TA. Following R2b, this should affect the TA / DIC ratio, but the observations do not show any deviations of the TA / DIC ratio from 1 . The missing TA is likely provided by pyrite formation (R12).

In the prodelta domain (Fig. 8), a similar set of reactions involving sulfate reduction and sulfide re-oxidation and precipitation is also visible with lower amplitude as sulfate depletion is only $5 \mathrm{mmol} \mathrm{L}^{-1}$. Oversaturation with respect to calcite reaches values ranging from 3 to 4 only below $15 \mathrm{~cm}$, and the $\mathrm{Ca}^{2+}$ decrease is limited and arises deeper. In the distal zone where $\Omega$ is around 2 down to $25 \mathrm{~cm}$, no calcium decrease is visible, indicating that precipitation does not occur.

As the alkalinity fluxes produced by anaerobic processes are high and likely not much reduced by reoxidation of reduced species in the oxic layer due to iron sulfide precipitation, net TA fluxes of the same order of magnitude as DIC fluxes are likely to occur. Therefore, the alkalinity buildup in the anoxic zone could diffuse across the oxic sediment layer and contribute to buffer bottom waters and increase $\mathrm{CO}_{2}$ storage capacity of these waters. The large precipitation of calcium carbonate in the proximal zone may have implications for the $\mathrm{CO}_{2}$ source potential from the sediment. Indeed, calcium carbonate precipitation generates $\mathrm{CO}_{2}(\mathrm{R} 2 \mathrm{~b})$, which can then be exported to the water column. In addition, calcium carbonate precipitation consumes TA. However, the order of magnitude of the TA consumption by carbonate precipitation in these sediments is below the quantity of TA produced by sulfate reduction. Without this TA flux, the $p \mathrm{CO}_{2}$ of the bottom waters in the prodelta of the Rhône would likely be much higher than observed.

\section{Conclusions}

This study demonstrated that the three major domains of the Rhône River prodelta are characterized by different organic and inorganic particulate carbon interactions. Close to the river mouth, where the carbon turnover is highest, the biogeochemical gradients are the strongest, resulting in high chemical fluxes across the SWI. This confirms that the biogeochemistry in the prodelta region is driven by the import and processing of material from the Rhône River.

The oxic reactions produce $\mathrm{CO}_{2}$ and create a $\mathrm{pH}$ drop of 0.6 to $0.8 \mathrm{pH}$ units and reduce $\Omega$. As a consequence, calcium carbonate might dissolve in the oxic layer, but the saturation state of bottom waters and porewaters just below the OPD suggests that this is unlikely to happen. The majority of oxygen is used for OM mineralization as most reduced species precipitate in anoxic sediments and do not contribute to oxygen consumption. The mineralization of OM, presumably by 
$\mathrm{Fe}$ and $\mathrm{Mn}$ oxides, increases $\mathrm{pH}$ and $\Omega$ below the oxic layer to several millimeters in depth.

The strong TA and DIC gradients observed in the sediments of the Rhône River prodelta suggest that OM mineralization is dominated by anaerobic processes. Close to the river mouth, where the OC content in the sediments is highest, sulfate reduction is the dominant mineralization process for OM degradation, creating a strong coupling between TA and DIC in porewater profiles. Despite its theoretical lowering effect on $\mathrm{pH}$, sulfate reduction is related to an increase of $\Omega$ by important alkalinity production and via the simultaneous $\mathrm{pH}$ increase by precipitation of iron-sulfate minerals. As a result, porewaters are oversaturated at all sampled stations. Calcium carbonate precipitation occurs in the proximal and in the prodelta domain, depleting the majority of dissolved calcium ions in the proximal domain. This carbonate precipitation could represent an additional $\mathrm{CO}_{2}$ source from the sediments to the water column, but is outbalanced by TA production by sulfate reduction. Due to this important anoxic TA production, the $p \mathrm{CO}_{2}$ of bottom waters remains relatively low compared to the high release of DIC due to OM mineralization.

\section{Data availability}

The dataset will soon be made available in the French repository Mistrals/SEDOO/Mermex (during October 2016). Metadata are already available at http://mistrals.sedoo.fr/?editDatsId=1373\&datsId= 1373\&project_name=MERMeX.

Acknowledgements. We thank David J. Burdige, an anonymous referee and J. Patrick Laceby for their constructive comments that helped increase the quality of the paper. Furthermore, we would like to thank Bruno Bombed and Jean-Pascal Dumoulin for their technical help during the DICASE cruise and in the laboratory. We also thank the captain and crew of the RV Tethys II (INSU) for their excellent work at sea. A lot of our gratitude is for the SNAPO-CO2 for the intercomparison of DIC and TA concentrations in our seawater samples. We are grateful to Celine Liorzou for the ICP-AES measurements and to Serge Miska for the help with the X-Ray diffraction analysis, and we want to thank Stephanie Duchamp-Alphonse for putting a manocalcimeter at our disposal. This research was financed by the Mistrals/MERMEX project (http://mermex.pytheas.univ-amu.fr/?page_id=62) and through the MERMEX Rivers action. This paper is LSCE contribution 5887.

Edited by: J. Middelburg

Reviewed by: D. Burdige and one anonymous referee

\section{References}

Aguilera, D. R., Jourabchi, P., Spiteri, C., and Regnier, P.: A knowledge-based reactive transport approach for the simulation of biogeochemical dynamics in Earth systems: earth system dynamics, Geochem. Geophys. Geosy., 6, 1-18, 2005.

Aller, R. C.: Mobile deltaic and continental shelf muds as suboxic, fluidized bed reactors, Mar. Chem., 61, 143-155, 1998.

Aller, R. C. and Blair, N. E.: Carbon remineralization in the Amazon-Guianas tropical mobile mudbelt: A sedimentary incinerator, Cont. Shelf. Res., 26, 2241-2259, 2006.

Andersson, A. J., Mackenzie, F. T., and Lerman, A.: Coastal ocean and carbonate system in the high $\mathrm{CO}_{2}$ world of the anthropocene, Am. J. Sci., 305, 875-918, 2005.

Andrews, D. and Bennet, A.: Measurements of diffusivity near the sediment-water interface with a fine-scale resistivity probe, Geochim. Cosmochim. Ac., 45, 2169-2175, 1981.

Antler, G., Turchyn, A. V., Herut, B. Davies, A., and Rennie, V. C. F.: Sulfur and oxygen isotope tracing of sulfate driven anaerobic methane oxidation in estuarine sediments, Estuar. Coast. Shelf Sci., 142, 4-11, 2014.

Arndt, S., Jørgensen, B. B., LaRowe, D. E., Middelburg, J. J., Pancost, R. D., and Regnier, P.: Quantifiying the degradation of organic matter in marine sediments: A review and synthesis, Earth Sci. Rev., 123, 53-86, 2013.

Bauer, J. E., Cai, W.-J., Raymond, P. A., Bianchi, T. S., Hopkinson, C. S., and Regnier, P. A. G.: The changing carbon cycle of the coastal ocean, Nature, 504, 61-70, 2013.

Ben-Yaakov, S.: pH buffering of pore water of recent anoxic marine sediments, Limnol. Oceanogr., 18, 86-94, 1973.

Berner, R. A.: Early diagenesis: A theoretical approach, Princeton University Press, 241 pp., 1980.

Bonifacio, P., Bourgeois, S., Labrune, C., Amouroux, J.-M., Escoubeyrou, K., Buscail, R., Romero-Ramirez, A., Lantoine, F., Vetion, G., Bichon, S., Desmalades, M., Riviere, M., Deflandre, B. and Gremare, A.: Spatiotemporal changes in surface sediment characteristics and benthic macrofauna composition off the Rhône River in relation to its hydrological regime, Estuar. Coast. Shelf Sci., 151, 196-209, 2014.

Boudreau, B. P., Canfield, D. E., and Mucci, A.: Early diagenesis in a marine sapropel, Mangrove Lake, Bermuda, Limnol Oceanogr., 37, 1738-1753, 1992.

Bourgeois, S., Pruski, A. M., Sun, M.-Y., Buscail, R., Lantoine, F., Kerhervé, P., Vétion, G., Rivière, B., and Charles, F.: Distribution and lability of land-derived organic matter in the surface sediments of the Rhône prodelta and the adjacent shelf (Mediterranean Sea, France): a multi proxy study, Biogeosciences, 8, 3107-3125, doi:10.5194/bg-8-3107-2011, 2011.

Broecker, W. S. and Peng, T.-H.: Gas exchange rates between air and sea, Tellus, 26, 21-35, 1974.

Burdige, D. J.: Estuarine and Coastal Sediments - Coupled Biogeochemical Cycling, Treatise, Estuar. Coast. Sci., 5, 279-316, 2011.

Burdige, D. J. and Komada, T.: Anaerobic oxidation of methane and the stoichiometry of remineralization processes in continental margin sediments, Limnol. Oceanogr., 56, 1781-1796, 2011.

Burdige, D. J., Zimmerman, R. C., and Hu, X.: Rates of carbonate dissolution in permeable sediments estimated from pore-water profiles: The role of sea grasses, Limnol. Oceanogr., 53, 549$565,2008$. 
Burdige, D. J., Hu, X., and Zimmermann, R. C.: The widespread occurence of coupled carbonate dissolution/reprecipitation in surface sediments on the Bahamas Bank, Am. J. Sci., 310, 492-521, 2010.

Cai, W.-J.: Estuarine and Coastal Ocean Carbon Paradox: $\mathrm{CO}_{2}$ Sinks or Sites of Terrestrial Carbon Incineration?, Annu. Rev. Mar. Sci., 3, 123-145, 2011.

Cai, W. J. and Reimers, C. E.: The development of $\mathrm{pH}$ and $p \mathrm{CO}_{2}$, microelectrodes for studying the carbonate chemistry of pore waters near the se

Cai, W.-J. and Sayles, F. L.: Oxygen penetration depths and fluxes in marine sediments, Mar. Chem., 52, 123-131, 1996. dimentwater interface, Limnol. Oceanogr., 38, 1762-1773, 1993.

Cai, W. J., Reimers, C. E., and Shaw, T.: Microelectrode studies of organic carbon degradation and calcite dissolution at a California Continental rise site, Geochim. Cosmochim. Ac., 59, 497-511, 1995.

Cai, W.-J., Zhao, P., and Wang, Y.: $\mathrm{pH}$ and $p \mathrm{CO}_{2}$ microelectrode measurements and the diffusive behaviour of carbon dioxide species in coastal marine sediments, Mar. Chem., 70, 133-148, 2000.

Cai, W.-J., Luther III, G. W., Cornwell, J. C., and Giblin, A. E.: Carbon Cycling and the Coupling Between Proton and Electron Tr16, 421-446, 2010.

Cathalot, C., Rabouille, C., Pastor, L., Deflandre, B., Viollier, E., Buscail, R., Grémare, A., Treignier, C., and Pruski, A.: Temporal variability of carbon recycling in coastal sediments influenced by rivers: assessing the impact of flood inputs in the Rhône River prodelta, Biogeosciences, 7, 1187-1205, doi:10.5194/bg7-1187-2010, 2010.

Cathalot, C., Rabouille, C., Tisnérat-Laborde, N., Toussaint, F., Kerhervé, P., Buscail, R., Loftis, K., Sun, M.-Y., Tronczynski, J., Azoury, S., Lansard, B., Treignier, C., Pastor, L., and Tesi, T.: The fate of river organic carbon in coastal areas: A study in the Rhône River delta using multiple isotopic $\left(\delta^{13} \mathrm{C}, \Delta^{14} \mathrm{C}\right)$ and organic tracers, Geochim. Cosmochim. Ac., 118, 33-55, 2013.

Charles, F., Coston-Guarini, J., Lantoine, F., Guarini, J.-M., and Yücel, M.: Ecogeochemical fate of coarse organic particles in sediments of the Rhône River prodelta, Estuar. Coast. Shelf Sci., 141, 97-103, 2014.

Charmasson, S., Radakovitch, O., Arnaud, M., Bouisset, P., and Pruchon, A.-S.: Long-core profiles of ${ }^{137} \mathrm{Cs},{ }^{134} \mathrm{Cs},{ }^{60} \mathrm{Co}$ and ${ }^{210} \mathrm{~Pb}$ in sediment near the Rhône River (Northwestern Mediterranean Sea), Estuaries, 21, 367-378, 1998.

Chen, C.-T. A. and Borges, A. V.: Reconciling opposing views on carbon cycling in the coastal ocean: Continental shelves as sinks and near-shore ecosystemsas sources of atmospheric $\mathrm{CO}_{2}$, DeepSea Res. Pt. II, 56, 578-590, 2009.

Chen, C.-T. A., Huang, T.-H., Fu, Y.-H., Bai, Y., and He, X.: Strong sources of $\mathrm{CO}_{2}$ in upper estuaries become sinks of $\mathrm{CO}_{2}$ in large river plumes, Current Opinion Environ. Sustain., 4, 179-185, 2012

Clayton, T. D. and Byrne, R. H.: Spectrophotometric seawater $\mathrm{pH}$ measurements: total hydrogen ion concentration scale calibration of $\mathrm{m}$-cresol purple and at-sea results, Deep-Sea Res. Pt. I, 40, 2115-2129, 1993.

Dai, M., Yin, Z., Meng, F., Liu, Q., and Cai, W.-J.: Spatial distribution of riverine DOC inputs to the ocean: an updated global synthesis, Current Opinion Environ. Sustain., 4, 170-178, 2012.
Dickson, A. G., Sabine, C. L., and Christian, J. R.: Guide to best practices for ocean $\mathrm{CO}_{2}$ measurements, PICES Special Publication 3, 2007.

Durrieu de Madron, X., Abassi, A., Heussner, S., Monaco, A., Aloisi, J. C., Radakovitch, O., Giresse, P., Buscail, R., and Kerherve, P.: Particulate matter and organic carbon budgets for the Gulf of Lions (NW Mediterranean), Oceanol. Ac., 23, 717-730, 2000.

Emerson, S. R. and Hedges, J. I.: Chemical Oceanography and the Marine Carbon Cycle, Cambridge University Press, 2008.

Estournel, C., Kondrachoff, V., Marsaleix, P., and Vehil, R.: The plume of the Rhone: numerical simulation and remote sensing, Cont. Shelf. Res., 17, 899-924, 1997.

Fenschel, T., King, G. M., and Blackburn, T. H.: Bacterial Biogeochemistry: The Ecophysiology of Mineral Cycling, 3rd Edn., Academic Press (Elsevier), 2012.

Froelich, P., Klinkhamm, G. P., Bender, M., Luedtke, N. A., Heath, G. R., Cullen, D., Dauphin, P., Hammond, D., Hartman, B., and Maynard, V.: Early oxidation of organic matter in pelagic sediments of the eastern equatorial Atlantic: suboxic diagenesis, Geochim. Cosmochim. Ac., 43, 1075-1090, 1979.

Gaillard, J.-F., Pauwels, H., and Michard, G.: Chemical diagenesis in coastal marine sediments, Oceanol. Ac., 12, 175-187, 1989.

García-García, A., Orange, D., Lorenson, T., Radakovitch, O., Tesi, T., Miserocchi, S., Berné, S., Friend, P. L., Nittrouer, C., and Normand, A.: Shallow gas off the Rhône prodelta, Gulf of Lions, Mar. Geol., 234, 215-231, 2006.

Glud, R. N.: Oxygen dynamics of marine sediments, Mar. Biol. Res., 4, 243-289, 2008.

Got, H. and Aloisi, J. C.: The Holocene sedimentation on the Gulf of Lions margin: a quantitative approach, Cont. Shelf. Res., 10, 841-855, 1990.

Grasshoff, K., Ehrhardt, M., and Kremling, K.: Methods of Seawater Analysis, Grasshoff, Ehrhardt and Kremling, Verlag Chemie GmbH, 419 pp., 1983.

Guieu, C., Martin, J. M., Thomas, A. J., and Elbaz-Poulichet, F.: Atmospheric Versus River Inputs of Metals to the Gulf of Lions, Total Concentrations, Partitioning and Fluxes, Mar. Poll. Bull., 22, 176-183, 1991.

Hales, B. and Emerson, S.: Calcite dissolution in sediments of the Cera Rise: In situ measurements of porewater $\mathrm{O}_{2}, \mathrm{pH}$ and $\mathrm{CO}_{2(\mathrm{aq})}$, Geochim. Cosmochim. Ac., 61, 501-514, 1997.

Hedges, J. I. and Keil, R. G.: Sedimentary organic matter preservation: an assessment and speculative synthesis, Mar. Chem., 49, 81-115, 1995.

Jahnke, R. A. and Jahnke, D. B.: Calcium carbonate dissolution in deep sea sediments: reconciling microelectrode, pore water and benthic flux chamber results, Geochim. Cosmochim. Ac., 68, 4759, 2004.

Jahnke, R. A., Craven, D. B., McCorkle, D. C., and Reimers, C. E.: $\mathrm{CaCO}_{3}$ dissolution in California continental margin sediments: the influence of organic matter remineralization, Geochim. Cosmochim. Ac., 61, 3587-3604, 1997.

Jourabchi, P., Van Cappellen, P., and Regnier, P.: Quantitative interpretation of $\mathrm{pH}$ distributions in aquatic sediments: A reactiontransport modeling approach, Am. J. Sci., 305, 919-956, 2005.

Komada, T., Reimers, C. E., and Boehme S. E.: Dissolved inorganic carbon profiles and fluxes determined using $\mathrm{pH}$ and $p \mathrm{CO}_{2}$ microelectrodes, Limnol. Ocennogr., 43, 769-778, 1998. 
Krumins, V., Gehlen, M., Arndt, S., Van Cappellen, P., and Regnier, P.: Dissolved inorganic carbon and alkalinity fluxes from coastal marine sediments: model estimates for different shelf environments and sensitivity to global change, Biogeosciences, 10, 371-398, doi:10.5194/bg-10-371-2013, 2013.

Lansard, B.: DICASE cruise, RV Téthys II, doi:10.17600/14007100, 2014.

Lansard, B., Rabouille, C., Denis, L., and Grenz, C.: In situ oxygen uptake rates by coastal sediments under the influence of the Rhône River (NW Mediterranean Sea), Cont. Shelf Res., 28, 1501-1510, 2008.

Lansard, B., Rabouille, C., Denis, L., and Grenz, C.: Benthic remineralization at the land-ocean interface: A case study of the Rhône River (NW Mediterranean Sea), Estuar. Coast. Shelf Sci., 81, 544-554, 2009.

Laruelle, G. G., Dürr, H. H., Lauerwald, R., Hartmann, J., Slomp, C. P., Goossens, N., and Regnier, P. A. G.: Global multi-scale segmentation of continental and coastal waters from the watersheds to the continental margins, Hydrol. Earth Syst. Sci., 17, 2029-2051, doi:10.5194/hess-17-2029-2013, 2013.

Lewis, E. and Wallace, D. W. R, Program developed for $\mathrm{CO}_{2}$ system calculations, ORNL/CDIAC-105, Carbon Dioxide Information Analysis Center, US Department of Energy, Oak Ridge National Laboratory, Tennessee, available at: http://cdiac.esd.ornl. gov/oceans/co2rprt.html (last access: June 2014), 1998.

Li, Y.-H. and S. Gregory: Diffusion of ions in sea water and in deepsea sediments, Geochim. Cosmochim. Ac., 88, 703-714, 1974.

Lueker, T. J., Dickson, A. G., and Keeling, C. D.: Ocean $p \mathrm{CO}_{2}$ calculated from dissolved inorganic carbon, alkalinity, and equations for $\mathrm{K}_{1}$ and $\mathrm{K}_{2}$ : validation based on laboratory measurements of $\mathrm{CO}_{2}$ in gas and seawater at equilibrium, Mar. Chem., 70, 105-119, 2000.

Mackenzie, F. T. Vink, S., Wollast, R., and Chou, L.: Comparative Geochemistry of Marine Saline Lakes, Physics and Chemistry of Lakes, 2nd Edn., Springer-Verlag, Berlin, 265-278, 1995.

McKee, B. A., Aller, R. C., Allison, M. A., Bianchi, T. S., and Kineke, G. C.: Transport and transformation of dissolved and particulate materials on continental margins influenced by major rivers: benthic boundary layer and seabed processes, Cont. Shelf. Res.,24, 899-926, 2004.

Millero, F. J.: Thermodynamics of the carbon dioxide system in seawater, Geochim. Cosmochim. Ac., 43, 1651-1661, 1979.

Millero, F. J.: Thermodynamics of the carbon dioxide system in the oceans, Geochim. Cosmochim. Ac., 59, 661-677, 1995.

Miralles, J., Radakovitch, T. O., and Aloisi, J.-C.: 210Pb sedimentation rates from the NorthwesternMediterranean margin, Mar. Geol., 216, 155-167, 2005.

Mojtahid, M., Jorissen, F., Lansard, B., and Fontanier, C.: Microhabitat selection of benthic foraminifera in sediments off the Rhône River mouth (NW Mediterranean), J. Foramin. Res., 40, 231-246, 2010

Mucci, A.: The solubility of calcite and aragonite in seawater at various salinities, temperatures and one atmosphere total pressure, Am. J. Sci., 283, 780-799, 1983.

Mucci, A., Sundby, B., Gehlen, M., Arakaki, T., Zhong, S., and Silverberg, N.: The fate of carbon in continental shelf sediments of eastern Canada: a case study, Deep-Sea Res. Pt. II., 47, 733-760, 2000 .
Nouet, J. and Bassinot, F.: Dissolution effects on the crystallography and $\mathrm{Mg} / \mathrm{Ca}$ content of planktonic foraminifera Gloorotalia tumida (Rotaliina) revealed by X-ray diffractometry, Geochem. Geophy. Geosy., 8, Q10007, doi:10.1029/2007GC001647, 2007.

Orr, J. C., Epitalon, J.-M., and Gattuso, J.-P.: Comparison of ten packages that compute ocean carbonate chemistry, Biogeosciences, 12, 1483-1510, doi:10.5194/bg-12-1483-2015, 2015.

Pastor, L., Cathalot, C., Deflandre, B., Viollier, E., Soetaert, K., Meysman, F. J. R., Ulses, C., Metzger, E., and Rabouille, C.: Modeling biogeochemical processes in sediments from the Rhône River prodelta area (NW Mediterranean Sea), Biogeosciences, 8, 1351-1366, doi:10.5194/bg-8-1351-2011, 2011a.

Pastor, L., Deflandre, B., Viollier, E., Cathalot, C., Metzger, E., Rabouille, C., Escoubeyrou, K., Lloret, E., Pruski, A. M., and Vétion, G.: Influence of the organic matter composition on benthic oxygen demand in the Rhône River prodelta (NW Mediterranean Sea), Cont. Shelf Res., 31, 1008-1019, 2011 b.

Pont, D.: Les débits solides du Rhône à proximité de son embouchure : données récentes (1994-1995)/The discharge of suspended sediments near to the mouth of the Rhône recent statistics (1994-1995), Revue de géographie de Lyon, 72, 23-33, 1997.

Rabouille, C., Denis, L., Dedieu, K., Stora, G., Lansard, B., and Grenz, C.: Oxygen demand in coastal marine sediments: comparing in situ microelectrodes and laboratory core incubations, J. Exp. Mar. Biol. Ecol., 285, 49-69, 2003.

Revsbech, N. P.: An oxygen microsensor with a guard cathode, Limnol. Oceanogr., 34, 474-478, 1989.

Roussiez, V., Aloisi, J.-C., Monaco, A., and Ludwig, W.: Early muddy deposits along the Gulf of Lions shoreline: A key for a better understanding of land-to-sea transfer of sediments and associated pollutant fluxes, Mar. Geol., 222-223, 345-358, 2005.

Roussiez, V., Ludwig, W., Monaco, A., Probst, J.-L., Bouloubassi, I., Buscail, R., and Saragoni, G.: Sources and sinks of sedimentbound contaminants in the Gulf of Lions (NW Mediterranean Sea): A multi-tracer approach, Cont. Shelf Reas. 26, 1843-1857, 2006.

Seeberg-Elverfeldt, J., Schlüter, M., Feseker, T. and Kölling, M.: Rhizon sampling of porewaters near the sediment-water interface of aquatic systems, Limnol. Oceanogr.-Methods, 3, 361371, 2005.

Sempéré, R., Charrière, B., Van Wambeke, F., and Cauwet, G.: Carbon inputs of the Rhone River to the Mediterranean Sea: Biogeochemical implications, Global Biogeochem. Cy., 14, 669-681, 2000.

Soetaert, K., Hofmann, A. F., Middelburg, J. J., Meysman, F. J. R., and Greenwood, J.: The effect of biogeochemical processes on pH, Mar. Chem., 105, 30-51, 2007.

Tabatai, M. A.: A rapid method for determination of sulfate in water samples, Environ. Lett., 7, 237-243, 1974.

Thomas, H., Schiettecatte, L.-S., Suykens, K., Koné, Y. J. M., Shadwick, E. H., Prowe, A. E. F., Bozec, Y., de Baar, H. J. W., and Borges, A. V.: Enhanced ocean carbon storage from anaerobic alkalinity generation in coastal sediments, Biogeosciences, 6, 267274, doi:10.5194/bg-6-267-2009, 2009. 
Toussaint F., Rabouille, C., Cathalot, C., Bombled, B., Abchiche, A., Aouji, O., Buchholtz, G., Clemençon, A., Geyskens, N., Répécaud, M., Pairaud, I., Verney, R., and Tisnérat-Laborde, N.: A new device to follow temporal variations of oxygen demand in deltaic sediments: the LSCE benthic station, Limnol. Oceanogr.Methods, 12, 729-741, 2014.
Van Cappellen, P. and Wang, Y.: Cycling of iron and Manganese in surface sediments: A general theory for the coupled transport and reaction of carbon, oxygen, nitrogen, sulfur, iron and manganese, Am. J. Sci., 296, 197-243, 1996. 